\title{
The 30 kb deletion in the APOBEC3 cluster decreases APOBEC3A and $A P O B E C 3 B$ expression and creates a transcriptionally active hybrid gene but does not associate with breast cancer in the European population
}

\author{
Katarzyna Klonowska¹, Wojciech Kluzniak², Bogna Rusak², Anna Jakubowska², \\ Magdalena Ratajska ${ }^{3}$, Natalia Krawczynska ${ }^{3}$, Danuta Vasilevska ${ }^{4}$, Karol Czubak ${ }^{1}$, \\ Marzena Wojciechowska ${ }^{1}$, Cezary Cybulski ${ }^{2}$, Jan Lubinski ${ }^{2}$ and Piotr Kozlowski ${ }^{1}$ \\ ${ }^{1}$ Department of Molecular Genetics, Institute of Bioorganic Chemistry, Polish Academy of Sciences, Poznan, Poland \\ ${ }^{2}$ Department of Genetics and Pathology, International Hereditary Cancer Center, Pomeranian Medical University, Szczecin, \\ Poland \\ ${ }^{3}$ Department of Biology and Medical Genetics, Medical University of Gdansk, Gdansk, Poland \\ ${ }^{4}$ Department of Gynecology, Centre of Obstetrics and Gynecology, Vilnius University Hospital Santariskiu Klinikos, Vilnius, \\ Lithuania \\ Correspondence to: Piotr Kozlowski, email: kozlowp@ibch.poznan.pl, kozlowp@yahoo.com \\ Keywords: $A P O B E C 3 B$, hereditary breast cancer, MLPA, copy number variation (CNV), meta-analysis \\ Received: April 25, $2017 \quad$ Accepted: June 10, $2017 \quad$ Published: July 19, 2017 \\ Copyright: Klonowska et al. This is an open-access article distributed under the terms of the Creative Commons Attribution License \\ 3.0 (CC BY 3.0), which permits unrestricted use, distribution, and reproduction in any medium, provided the original author and \\ source are credited.
}

\section{ABSTRACT}

$A P O B E C 3 B$, in addition to other members of the $A P O B E C 3$ gene family, has recently been intensively studied due to its identification as a gene whose activation in cancer is responsible for a specific pattern of massively occurring somatic mutations. It was recently shown that a common large deletion in the APOBEC3 cluster (the APOBEC3B deletion) may increase the risk of breast cancer. However, conflicting evidence regarding this association was also reported. In the first step of our study, using different approaches, including an in-house designed multiplex ligation-dependent probe amplification assay, we analyzed the structure of the deletion and showed that although the breakpoints are located in highly homologous regions, which may generate recurrent occurrence of similar but not identical deletions, there is no sign of deletion heterogeneity. This knowledge allowed us to distinguish transcripts of all affected genes, including the highly homologous canonical $A P O B E C 3 A$ and $A P O B E C 3 B$, and the hybrid $\triangle P O B E C 3 A / A P O B E C 3 B$ gene. We unambiguously confirmed the presence of the hybrid transcript and showed that the $A P O B E C 3 B$ deletion negatively correlates with $A P O B E C 3 A$ and $\triangle P O B E C 3 B$ expression and positively correlates with APOBEC $3 A / A P O B E C 3 B$ expression, whose mRNA level is $>10$-fold and $>1500$-fold lower than the level of $\triangle P O B E C 3 A$ and $\triangle P O B E C 3 B$, respectively. In the next step, we performed a large-scale association study in three different cohorts ( 2972 cases and 3682 controls) and showed no association of the deletion with breast cancer, familial breast cancer or ovarian cancer. Further, we conducted a meta-analysis that confirmed the lack of the association of the deletion with breast cancer in non-Asian populations. 


\section{INTRODUCTION}

Breast cancer is the primary cause of cancerassociated death among women worldwide. The probability of developing breast cancer is modulated by an interplay of lifestyle, environmental, and genetic factors. The overall heritability $\left(\mathrm{h}^{2}\right)$ of breast cancer was estimated at approximately $30 \%$ [1]. Inherited breast cancer cases that aggregate in families constitute five to ten percent of all breast cancer cases. Highly penetrant germline mutations in BRCA1 and BRCA2 and in several genes associated with various hereditary cancer syndromes explain $16-40 \%$ of all breast cancer cases that aggregate in families [2-4]. Moreover, it is estimated that mutations in several susceptible genes of moderate penetrance, e.g., ATM, CHEK2 or NBN, account for another $5 \%$ of all familial breast cancer cases $[2,5,6]$. Recently, international collaborative analyses involving genome-wide association studies (GWASs) have revealed common low-penetrance single nucleotide polymorphisms (SNPs) in 94 loci that are individually associated with breast cancer. It is assumed that the cooperative effect of the identified SNPs may underlie more than $20 \%$ of breast cancer heritability [7-9]. Overall, the genetic background of breast cancer predisposition in approximately $50 \%$ of breast cancer cases aggregated in families still remains to be explained $[4,7]$.

It was presumed that investigating copy number variants (CNVs) may uncover a substantial part of still unidentified genetic loci related to the susceptibility to various complex diseases [10]. CNVs have been shown to be associated with several complex diseases, including HIV infection and AIDS development [11], osteoporosis [12], Crohn's disease [13] and autism [14]. Recently, it was also suggested that CNVs may underlie hidden susceptibility to breast cancer [15-17]. One common CNV that potentially increases the risk of breast cancer is the deletion of the $A P O B E C 3 B$ gene, which occurs with a high allelic frequency in East Asian (37\%), Amerindian (58\%) and Oceanic populations $(93 \%)$ and with a moderate $(6 \%)$ or low (1\%) allelic frequency in European and African populations, respectively [18]. The germline $A P O B E C 3 B$ deletion, comprising an $\sim 30 \mathrm{~kb}$ genomic region, extends between the last noncoding exon of $A P O B E C 3 A$ and the eighth exon of $A P O B E C 3 B$ and leads to the complete removal of the $A P O B E C 3 B$ protein-coding region. It was suggested that as a result of the $A P O B E C 3 B$ deletion, a hybrid gene, $A P O B E C 3 A / A P O B E C 3 B$, which possesses a coding sequence of $A P O B E C 3 A$ (exon 1 - exon 5) and 3' untranslated region (3'UTR) from $A P O B E C 3 B$ (exon 8 ), is generated. It can be assumed that transcript generated from the $A P O B E C 3 B$ deletion allele is subjected to different cellular regulation. Although the function of the two distinct APOBEC $3 \mathrm{~A}$ and $\mathrm{APOBEC} 3 \mathrm{~B}$ proteins is being intensively studied (reviewed in [19-24]), little is known about the influence of the germline $A P O B E C 3 B$ deletion on the expression of affected genes (genes overlapped by the $A P O B E C 3 B$ deletion, i.e., $A P O B E C 3 A$, $A P O B E C 3 B$, and the $A P O B E C 3 A / A P O B E C 3 B$ hybrid). Therefore, direct evidence that the presumed $A P O B E C 3 A$ / $A P O B E C 3 B$ hybrid transcript actually arises and a detailed elucidation of its structure are of high importance. The knowledge of the exact structure of the hybrid transcript is vital for the design of a comprehensive tests for analysis of the influence of the $A P O B E C 3 B$ deletion genotype on the expression of $A P O B E C 3 B, A P O B E C 3 A$ and the $A P O B E C 3 A / A P O B E C 3 B$ hybrid gene, which would deepen the current knowledge of the functional consequences of the $A P O B E C 3 B$ deletion.

Several associations of the $A P O B E C 3 B$ deletion with different complex human diseases have already been reported [17, 25-42], including an association of the $A P O B E C 3 B$ deletion with breast cancer risk in a Chinese population $(\mathrm{OR}=1.31 / 1.76$ for one/two copies of the deletion) identified by Long and coworkers [17] and in two smaller studies in two other Asiatic populations, i.e., Iranian [36] and Malaysian [40]. In contrast, association of the $A P O B E C 3 B$ deletion with breast cancer is much less conclusive in European populations. The association was confirmed by another study of the Long group in a European-American population [31] but not in a Swedish population [37]. The association was also not confirmed in two smaller studies in Indian [38] and Moroccan [39] populations. It was concluded that in the Caucasian population, the relationship of the $A P O B E C 3 B$ deletion with increased breast cancer risk cannot be convincingly stated; therefore, further large-scale comprehensive association studies are necessary [43]. The currently available results report risk related to the $A P O B E C 3 B$ deletion in groups of unselected breast cancer cases. The role of the $A P O B E C 3 B$ deletion in familial breast cancer predisposition remains to be elucidated.

The APOBEC 3A and APOBEC3B proteins belong to Activation-Induced Cytidine Deaminase (AID)/ Apolipoprotein B mRNA Editing Enzyme, Catalytic Polypeptide-like (APOBEC) family, which consists of 11 cytidine deaminases. APOBEC3A and APOBEC3B possess the capability of introducing sequence alterations in single-stranded DNA (ssDNA) and are involved in various vital cellular processes (reviewed in $[19,20]$ ), including innate immune response against retroviruses (e.g., HTLV1) [44] and DNA viruses [e.g., HBV (e.g., [32, 45, 46]) and HPV (e.g., [47, 48])], regulation of retrotransposon element movement (e.g., [49-51]), and regulation of DNA methylation (e.g., [52-54]). More recently, APOBEC3B and APOBEC3A were also reported to be mutagenic enzymes whose activation in cancer is responsible for specific patterns of massively occurring somatic mutations [55, 56], referred to as kataegis (from the Greek for "thunderstorm") [57] or "mutation clusters" [58]. These patterns were observed in several cancer types, including breast cancer [59-62]. However, newer reports 
indicate that some controversies regarding specificities and the role of particular APOBEC3s in kataegis also exist $[63,64]$.

In this study, we determined the exact structure of the hybrid $A P O B E C 3 A / A P O B E C 3 B$ gene and provided direct evidence of the presence of the hybrid $A P O B E C 3 A / A P O B E C 3 B$ transcript in individuals carrying allele with the $A P O B E C 3 B$ deletion. We also analyzed the relationship between the $A P O B E C 3 B$ deletion genotypes and the expression of the affected genes, i.e., $A P O B E C 3 A$, $A P O B E C 3 B$ and hybrid $A P O B E C 3 A / A P O B E C 3 B$, and showed that the $A P O B E C 3 B$ deletion negatively correlates with the expression of $A P O B E C 3 A$ and $A P O B E C 3 B$ and positively correlates with expression of $A P O B E C 3 A$ / $A P O B E C 3 B$. We also performed a large-scale, case-control study of the association of the $A P O B E C 3 B$ deletion with breast and ovarian cancer in three different European cohorts (encompassing >6500 samples), which revealed the lack of association of the $A P O B E C 3 B$ deletion with breast and ovarian cancer in European populations. To obtain a more global view of the role of the $A P O B E C 3 B$ deletion in cancer predisposition, we also conducted a comprehensive meta-analysis, considering all association studies of the deletion with breast and other types of cancer.

\section{RESULTS}

\section{Design of the A3Bdel_PCR assay and comprehensive analysis of the structure of the APOBEC $3 B$ deletion}

As breakpoints of the deletion overlap with extended highly homologous regions (Figure 1, segmental duplications of $95 \%$ similarity cover almost entire $A P O B E C 3 A$ and 3'-half of $A P O B E C 3 B$ ), determination of their exact positions may be redundant. Therefore, in the first step we designed a simple single-tube A3Bdel_PCR assay to distinguish the reference $(\mathrm{A} 3 \mathrm{~B}+)$ and the deletion (A3B-) alleles and to unequivocally confirm the exact size and position of the deletion. The test takes advantage of nucleotide positions specific for particular duplicated regions defined based on a careful analysis of the reference sequence (hg19) and on previous results [18]. The assay consists of three PCR primers, i.e., one forward primer (F) and two distinct reverse primers (R1 and R2) (Figure 1). $\mathrm{F}$ is located on the border of $A P O B E C 3 A$ intron 3 and exon 4, upstream of the presumed 5'-breakpoint of the $A P O B E C 3 B$ deletion; $\mathrm{R} 1$ is located in the $A P O B E C 3 A$ exon 5 downstream of the presumed 5 '-breakpoint of the deletion; and R2 is specific to the sequence within the $A P O B E C 3 B$ exon 8 downstream of the presumed 3'-breakpoint of the deletion (Figure 1A). R1 and $\mathrm{R} 2$ primers distinguish the $\mathrm{A} 3 \mathrm{~B}+$ and $\mathrm{A} 3 \mathrm{~B}$ - alleles, respectively. The primers are localized in such a way that the amplicons corresponding to the $\mathrm{A} 3 \mathrm{~B}+$ and the $\mathrm{A} 3 \mathrm{~B}$ - are of different lengths, which distinguish them and identify the $A P O B E C 3 B$ deletion genotypes (Figure 1). With the use of the designed A3Bdel_PCR primers, we performed a sequencing analysis that determined the deletion breakpoints at a single-nucleotide resolution (Figure 1). The sequencing analysis refined the $A P O B E C 3 B$ deletion to a $29936 \mathrm{bp}$ genomic region. It has to be noted, however, that the 5 ' or 3 ' breakpoints of the $A P O B E C 3 B$ deletion lie within a $350 \mathrm{bp}$ sequence that is identical on both sides of the deletion; therefore, the exact position of the deletion depends on the assumed convention/ nomenclature (according to the HGVS nomenclature: GRCh37/hg19: g.chr22:39358631_g.chr22:39388566del or APOBEC3A:c.717_APOBEC3B:c.1265del).

The location of the breakpoints of the deletion in almost identical, segmentally duplicated regions may induce recurrent occurrence of similar but not identical deletions arising due to non-allelic homologous recombination (NAHR). Therefore, to exclude the potential heterogeneity of the $A P O B E C 3 B$ deletion, we utilized multiplex ligation-dependent probe amplification (MLPA), which is the method of choice for the analysis of large deletions. Because commercial MLPA assays are available only for a limited number of genes and there is no such assay for the $A P O B E C 3 A$ and $A P O B E C 3 B$ genes, we designed a homemade A3Bdel_MLPA assay. The assay was designed and generated according to a strategy previously developed in our group [65-68]. The A3Bdel_ MLPA assay is composed of 12 probes, i.e., 4 probes located in close proximity to the breakpoints within flanking sequences of the deletion, 5 probes located in the presumed deletion region, and 3 control probes specific to copy-number stable regions located in chromosomes 1, 2, and 22 (for details, see Materials and Methods, Figure 1A and Supplementary Table 1). The A3Bdel_MLPA probe set was verified to provide robust, high-quality results in a series of optimization experiments performed using a set of reference gDNA samples. The optimized A3Bdel_MLPA assay was used to analyze two panels of gDNA samples, i.e., a panel of 31 samples from the HapMap project and a panel of 17 samples derived from women with breast and/or ovarian cancer with different $A P O B E C 3 B$ deletion genotypes that were previously determined with the use of the A3Bdel_PCR assay (Figure 1D and Supplementary Figure 1). We observed a perfect correlation between the obtained MLPA patterns and the APOBEC $3 B$ deletion genotypes identified in the A3Bdel_PCR analysis, which indicates the lack of heterogeneity in the structure of the $A P O B E C 3 B$ deletion.

\section{Effect of the $A P O B E C 3 B$ deletion on the expression of the affected genes}

In the first step, to assess the effect of the $A P O B E C 3 B$ deletion on $A P O B E C 3 A$ and $A P O B E C 3 B$ expression, we took advantage of whole genome mRNA 
profiling datasets regarding panels of HapMap samples derived from LCLs (lymphoblast cell lines) from B-lymphocytes. The genome-wide expression datasets were generated for 270 and 45 samples from basic (phase I/II) HapMap panel, with the use of microarray [69] and RNAseq [70] technology, respectively. From the datasets, we extracted data regarding the expression levels of $A P O B E C 3 A$ and $A P O B E C 3 B$ and compared them with the $A P O B E C 3 B$ deletion genotypes determined for these samples by [18] and independently determined by us (data not shown). As shown in Figure $2 \mathrm{~A}$, the $A P O B E C 3 B$ deletion genotype (presence of the deletion) negatively
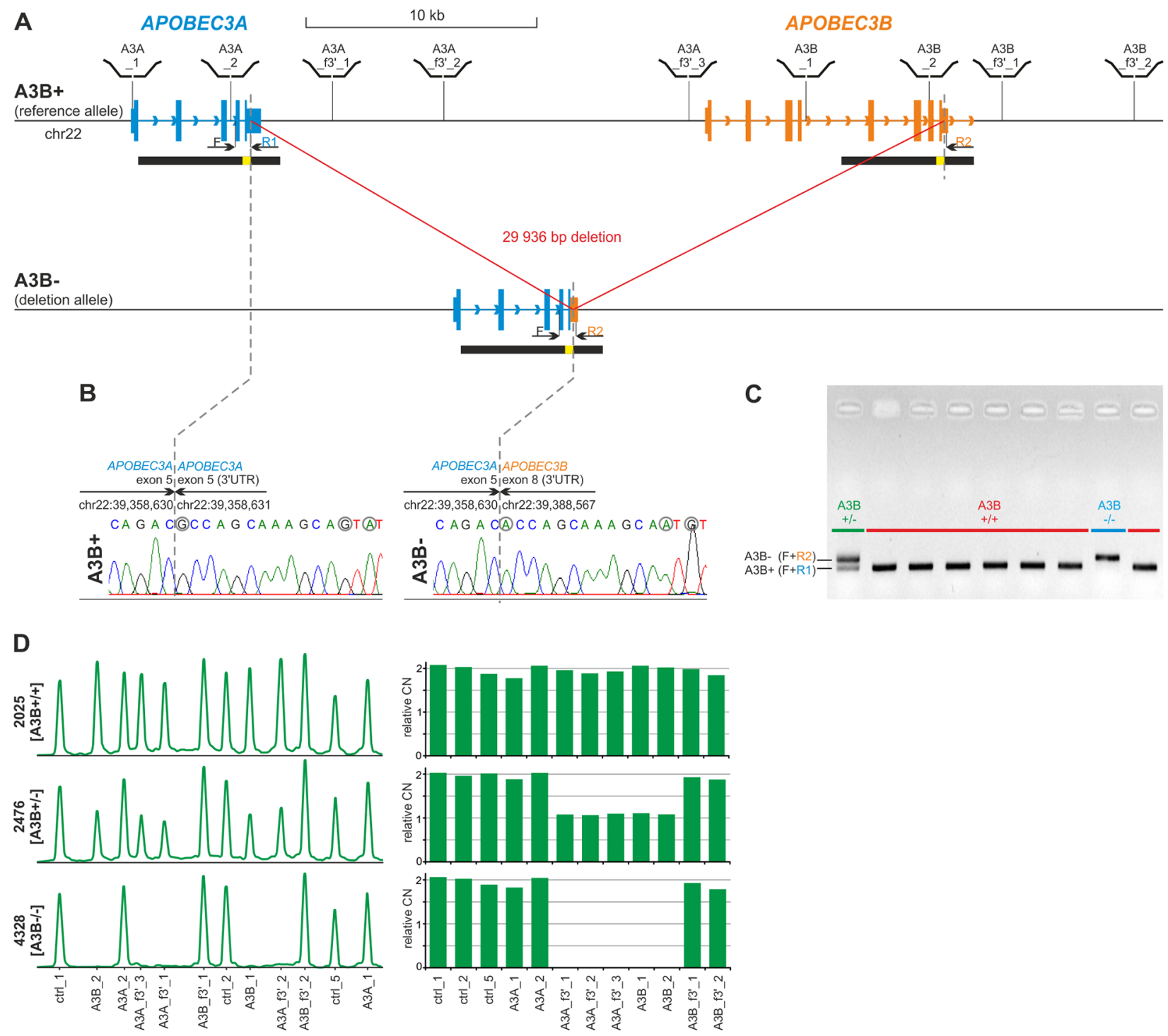

Figure 1: Structure of the $A P O B E C 3 B$ deletion and design of the PCR-based and MLPA-based genotyping assays. (A) Structure of $\mathrm{A} 3 \mathrm{~B}+$ and $\mathrm{A} 3 \mathrm{~B}-$ alleles. Blue and orange vertical rectangles indicate exons of $A P O B E C 3 A$ and $A P O B E C 3 B$, respectively. Higher and lower rectangles indicate coding and UTR sequences, respectively. Arrowheads along intron lines indicate the direction of the genes. Black horizontal bars under the gene schemes indicate highly homologous ( $95 \%)$ segmentally duplicated regions, with a yellow inset indicating $350 \mathrm{bp}$ redundant fragment of 100\% homology. Positions of MLPA probes used for A3Bdel_MLPA assay are schematically depicted above the region map; positions of F, R1 and R2 primers used for sequencing and in A3Bdel_PCR assay are indicated under the map. (B) Results of Sanger sequencing of deletion breakpoints amplified with the F-R1 (left-hand side) and F-R2 (right-hand side) pairs of primers, respectively. Dotted lines indicate exact breakpoint positions according to HGVS recommendation (after the last nucleotide of the redundant sequence). Sequencing was performed using homozygous $\mathrm{A} 3 \mathrm{~B}+/+$ and $\mathrm{A} 3 \mathrm{~B}-/-$ samples. Nucleotides that distinguish the $\mathrm{A} 3 \mathrm{~B}+$ and A3B- alleles are circled in gray. (C) Visualization (agarose gel with EtBr staining) of PCR products of the A3Bdel_PCR assay. A3B+/+ genotypes without deletion; A3B-/- genotype with homozygous deletion; A3B+/- genotype with heterozygous deletion. (D) Exemplary results of the A3Bdel_MLPA analysis. The left-hand side panel: the MLPA electropherograms of the representative samples with A3B+/+, $\mathrm{A} 3 \mathrm{~B}+/-$, and $\mathrm{A} 3 \mathrm{~B}-/-$ genotypes. The probe IDs are shown under the electropherograms. The right-hand side panel: bar plots (corresponding to the electropherograms shown on left-hand side) representing the normalized copy number value (y-axis) of each probe (x-axis). 
correlates with $A P O B E C 3 B$ expression [both microarray $(\mathrm{R}=-0.74, \mathrm{p}<0.001)$ and RNAseq $(\mathrm{R}=-0.65, \mathrm{p}<0.001)$ data] but not with $A P O B E C 3 A$ expression. It has to be noted, however, that lack of correlation of $A P O B E C 3 A$ expression with the deletion genotype may result from (i) very low levels of $A P O B E C 3 A$ expression (in comparison to $A P O B E C 3 B$ ) in some tissues and cell subsets, including $\mathrm{T}$ - and B-lymphocytes and breast cancer cell lines [55, 64, 71-73], or (ii) high homology between $A P O B E C 3 A$ and $A P O B E C 3 B$ and other $A P O B E C$ family members that might lead to the mismapping of RNAseq reads or crosshybridization of $A P O B E C 3 A$-specific probes [55, 64]. The lack of consistency in the measurement of the $A P O B E C 3 A$ expression level between the studies (in [70], it is lower than the level of $A P O B E C 3 B$, but in [69], it is higher than the level of $A P O B E C 3 B$ ) strongly suggests the occurrence of the cross-hybridization.
Therefore, to further investigate the effect that the $A P O B E C 3 B$ deletion has on the expression of $A P O B E C 3 A$ and $A P O B E C 3 B$ as well as the $A P O B E C 3 A / A P O B E C 3 B$ hybrid gene, occurring in the presence of the $A P O B E C 3 B$ deletion, we performed our own experimental analysis. First, we performed a sequencing analysis of the presumed $A P O B E C 3 B / A P O B E C 3 A$ hybrid transcript. The analysis unequivocally confirmed that the transcript is actually generated from the allele with the $A P O B E C 3 B$ deletion and defined its structure at a single-nucleotide resolution (Supplementary Figure 2). Taking advantage of the gathered information about the precise sequence structure of the $A P O B E C 3 B$ deletion and the hybrid transcript, we designed A3A_exp, A3B_exp and A3A/A3B_exp assays for expression analysis that distinguished the hybrid $A P O B E C 3 A / A P O B E C 3 B$ transcript from the canonical $A P O B E C 3 A$ and $A P O B E C 3 B$ transcripts (for details,
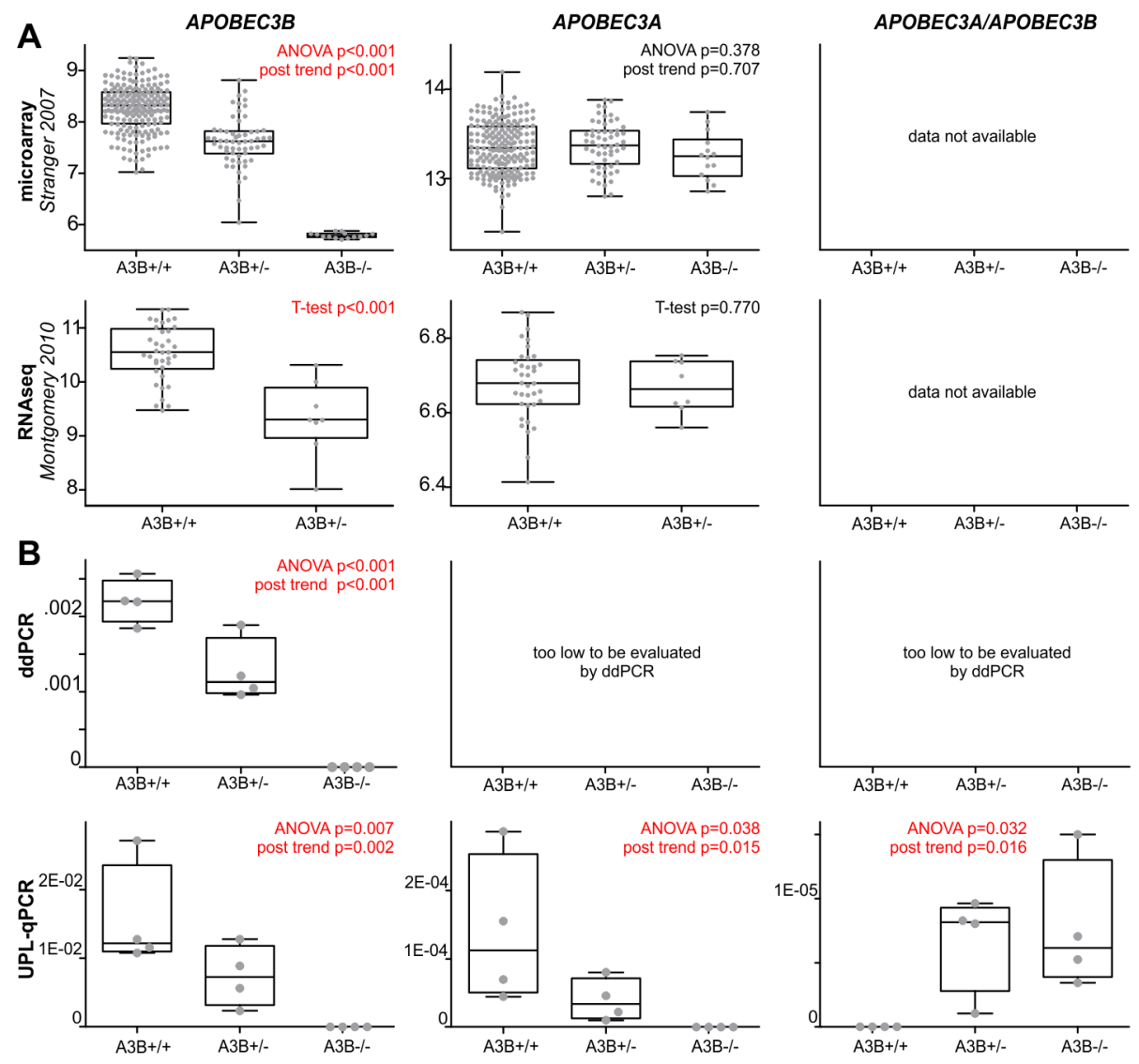

Figure 2: Effect of the $A P O B E C 3 B$ deletion on the expression of the affected genes, i.e., $A P O B E C 3 B, A P O B E C 3 A$, and APOBEC 3 A/APOBEC3B. (A) Comparison of the $A P O B E C 3 B$ deletion genotypes (A3B+/+, A3B+/-, A3B-/-; x-axes) in HapMap samples with relative expression (y-axes) level of the affected genes (indicated above) retrieved from microarray (upper row, [69]) and RNAseq (lower row, [70]) whole genome mRNA profiling datasets. It has to be noted that panel of HapMap samples analyzed in RNAseq study did not comprise samples with A3B-/- genotype. (B) Experimental analysis of expression of the affected genes in 12 HapMap cell lines with $\mathrm{A} 3 \mathrm{~B}+/+(\mathrm{n}=4), \mathrm{A} 3 \mathrm{~B}+/-(\mathrm{n}=4)$ and $\mathrm{A3B}-/-(\mathrm{n}=4)$. The expression analysis was performed with ddPCR (upper row) and UPL-qPCR (lower row). Note that due to very low levels of $A P O B E C 3 A$ and $A P O B E C 3 A / A P O B E C 3 B$ expression ( $>1000$ lower than $A P O B E C 3 B)$, they could not be reliably evaluated with ddPCR. The box-and-whisker plots summarize the distribution of the relative expression data points determined by microarray, RNAseq, ddPCR, and UPL-qPCR. The band inside of each box represents the median, and the upper and lower edges of the box represent 1 st and 3rd quartile of distribution. Whiskers indicate the lowest and the highest observed values. 
see Materials and Methods). For the purpose of the analysis, we selected 12 LCLs from the HapMap project representing different $A P O B E C 3 B$ genotypes, i.e., 4 cell lines with a reference $A P O B E C 3 B$ genotype $(\mathrm{A} 3 \mathrm{~B}+/+$; $2 A P O B E C 3 B$ copies), 4 cell lines with a heterozygous deletion of $A P O B E C 3 B$ (A3B+/-; 1 APOBEC 3B copy), and 4 cell lines with a homozygous deletion of $A P O B E C 3 B$ (A3B-/-; 0 APOBEC3B copies). The A3A_exp, A3B_exp and $\mathrm{A} 3 \mathrm{~A} / \mathrm{A} 3 \mathrm{~B}$ _exp assays were utilized for the evaluation of the expression levels in all the LCLs using droplet digital PCR (ddPCR) method. The ddPCR analysis revealed a negative correlation between the $A P O B E C 3 B$ deletion genotype and the expression of the $A P O B E C 3 B$ gene. In cell lines with $\mathrm{A} 3 \mathrm{~B}+/+, \mathrm{A} 3 \mathrm{~B}+/-$ and $\mathrm{A} 3 \mathrm{~B}-/-$ genotypes, $A P O B E C 3 B$ expression decreased gradually in a nearly linear manner $(\mathrm{R}=-0.96, \mathrm{p}<0.001)$ (Figure $2 \mathrm{~B}$ and Supplementary Figure 3 ). However, due to the very low level signal of $A P O B E C 3 A$ and $A P O B E C 3 A / A P O B E C 3 B$, we were not able to reliably evaluate their expression with ddPCR. Therefore, in the next step, we used a UPLqPCR technique that has a higher dynamic range than ddPCR. With the use of UPL-qPCR, we confirmed the negative correlation between the $A P O B E C 3 B$ deletion genotype and $A P O B E C 3 B$ expression $(\mathrm{R}=-0.82, \mathrm{p}=0.002)$ and revealed a negative and positive correlation between the $A P O B E C 3 B$ deletion genotype and the expression of $A P O B E C 3 A(\mathrm{R}=-0.70, \mathrm{p}=0.015)$ and the expression of $A P O B E C 3 A / A P O B E C 3 A(\mathrm{R}=0.67, \mathrm{p}=0.016)$, respectively (Figure 2B). As shown in Figure 2B, the expression of $A P O B E C 3 A$ and $A P O B E C 3 A / A P O B E C 3 B$ is very low and is, respectively, $\sim 130$-fold and $>1500$-fold lower than the expression of $A P O B E C 3 B$. Surprisingly, our analysis revealed that $A P O B E C 3 A / A P O B E C 3 B$ hybrid expression is substantially lower ( $\sim 12$-fold) than the expression of canonical $A P O B E C 3 A$, which indicates the role of the 3 'UTR in the differential regulation of these genes and that $A P O B E C 3 A / A P O B E C 3 B$ does not compensate for the lack of $A P O B E C 3 A$ dosage.

\section{Analysis of the association of the $A P O B E C 3 B$ deletion with breast and ovarian cancer risk}

For association analysis, we used several casecontrol set-ups from three different cohorts, i.e., GDANSK (523 BC-cases; 343 OC-cases; 853 controls), SZCZECIN (2009 BC-cases; 2005 controls; $615 \mathrm{NH-controls),} \mathrm{and}$ VILNIUS (97 OC-cases; 209 controls) (for details see Materials and Methods). The size of cumulative breast cancer case-control groups was estimated based on the frequency of the deletion in the European population ( $11-13 \%$ - based on our preliminary results and [18]) and expected effect (OR 1.3 - estimated based on previous studies, i.e., $[17,31])$ of the $A P O B E C 3 B$ deletion in order to obtain adequate statistical power $(>90 \%)$ of the analysis. All samples were genotyped using a simple single tube A3Bdel_PCR assay (for details see "Design of the A3Bdel_PCR assay and comprehensive analysis of the structure of the $A P O B E C 3 B$ deletion" and Materials and Methods). The distribution of the $A P O B E C 3 B$ deletion in control samples in all three groups was in good agreement with that expected under Hardy-Weinberg equilibrium (HWE) ( $p>>0.05)$, which indicates the high quality of the obtained genotyping results and the lack of bias in the detection of homozygous and heterozygous deletions. Logistic regression was used to derive odds ratios (ORs) and $95 \%$ confidence intervals (CIs) for the associations between the $A P O B E C 3 B$ deletion and cancer risk.

Numbers and frequencies of alleles and genotypes identified in the case and control groups are summarized in Table 1 (breast cancer association study) and Table 2 (ovarian cancer association study). In the association analyses, we focused mostly on the dominant model of inheritance ( $\mathrm{A} 3 \mathrm{~B}+/-$ and $\mathrm{A} 3 \mathrm{~B}-/-$ vs. $\mathrm{A} 3 \mathrm{~B}+/+)$ (Tables 1 and 2), but we also performed association analysis assuming additive and recessive models of inheritance (Supplementary Tables 2 and 3). The latter two models have much lower statistical power due to the low frequency $(\leq 1 \%)$ of homozygous deletions (A3B-/genotypes).

As shown in Table 1, the frequency of the $A P O B E C 3 B$ deletion in breast cancer cases does not significantly differ from that observed in population controls in GDANSK[OR $(95 \% \mathrm{CI})=1.31(0.94-1.82)$, $\mathrm{p}=0.11)]$ or SZCZECIN [OR $(95 \% \mathrm{CI})=0.89(0.74-1.07)$, $\mathrm{p}=0.20]$. It also does not differ from cancer-free controls (SZCZECIN-NH controls; negative for any cancer and negative for family history of cancer) $[\mathrm{OR}(95 \% \mathrm{CI})=1.03(0.78-1.36), \mathrm{p}=0.83] . \quad$ To increase the power of the analysis, we combined SZCZECIN and GDANSK cohorts but observed no association $[\mathrm{OR}(95 \% \mathrm{CI})=0.98(0.83-1.15), \mathrm{p}=0.79]$. Adjusting for the origin of the samples did not significantly influence the results. We also did not see an association of the $A P O B E C 3 B$ deletion with familial breast cancer cases, which were selected from the GDANSK and SZCZECIN breast cancer cases [OR $(95 \% \mathrm{CI})=1.06(0.82-1.36)$, $\mathrm{p}=0.67]$.

The $A P O B E C 3 B$ deletion also does not show association with ovarian cancer in either GDANSK $[\mathrm{OR}(95 \% \mathrm{CI})=0.77(0.50-1.19), \mathrm{p}=0.24] \quad$ or VILNIUS $[\mathrm{OR}(95 \% \mathrm{CI})=0.66(0.27-1.61), \mathrm{p}=0.36]$. It also does not associate with ovarian cancer in a combined GDANSK/ VILNIUS cohort $[\mathrm{OR}(95 \% \mathrm{CI})=0.75(0.51-1.10), \mathrm{p}=0.14]$. Adjusting for the origin of the samples did not significantly influence the results.

\section{Meta-analysis of association studies of the $A P O B E C 3 B$ deletion with cancer}

The association of the $A P O B E C 3 B$ deletion with cancer has been analyzed within eleven case-control studies conducted in populations of different ethnicities, 
Table 1: Analysis of the association of the $A P O B E C 3 B$ deletion with breast cancer risk using dominant model of inheritance (A3B+/- and A3B-/- vs. A3B $+/+$ )

\begin{tabular}{|c|c|c|c|c|c|}
\hline group & Genotypes & No of cases $(\%)$ & No of controls $(\%)$ & OR(95\%CI) & $\begin{array}{c}\text { Adjusted } \\
\text { OR(95\%CI) }\end{array}$ \\
\hline \multirow{4}{*}{$\begin{array}{l}\text { GDANSK } \\
\text { BC cases }(n=523) \text { vs. } \\
\text { unselected controls } \\
(n=853)\end{array}$} & $\mathrm{A} 3 \mathrm{~B}+/+$ & $450(86.04 \%)$ & $759(88.98 \%)$ & \multirow{4}{*}{$\begin{array}{c}1.31(0.94-1.82) \\
p=0.11\end{array}$} & \multirow{4}{*}{-} \\
\hline & $\mathrm{A} 3 \mathrm{~B}+/-$ & $71(13.58 \%)$ & $91(10.67 \%)$ & & \\
\hline & $\mathrm{A} 3 \mathrm{~B}-1-$ & $2(0.38 \%)$ & $3(0.35 \%)$ & & \\
\hline & $\mathrm{A} 3 \mathrm{~B}+/-$ and $\mathrm{A} 3 \mathrm{~B}-/-$ & $73(13.96 \%)$ & $94(11.02 \%)$ & & \\
\hline \multirow{4}{*}{$\begin{array}{l}\text { SZCZECIN } \\
\text { BC cases }(n=2009) \text { vs. } \\
\text { unselected controls } \\
(n=2005)\end{array}$} & $\mathrm{A} 3 \mathrm{~B}+/+$ & $1764(87.80 \%)$ & $1733(86.43 \%)$ & \multirow{4}{*}{$\begin{array}{c}0.89(0.74-1.07) \\
p=0.20\end{array}$} & \multirow{4}{*}{$\begin{array}{c}0.90(0.75-1.08)^{a} \\
p=0.26\end{array}$} \\
\hline & $\mathrm{A} 3 \mathrm{~B}+/-$ & $235(11.70 \%)$ & $267(13.32 \%)$ & & \\
\hline & $\mathrm{A} 3 \mathrm{~B}-1-$ & $10(0.50 \%)$ & $5(0.25 \%)$ & & \\
\hline & $\mathrm{A} 3 \mathrm{~B}+/-$ and $\mathrm{A} 3 \mathrm{~B}-/-$ & $245(12.20 \%)$ & $272(13.57 \%)$ & & \\
\hline \multirow{4}{*}{$\begin{array}{l}\text { SZCZECIN } \\
\text { BC cases }(n=2009) \text { vs. } \\
\text { NH-controls }(n=615)\end{array}$} & $\mathrm{A} 3 \mathrm{~B}+/+$ & $1764(87.80 \%)$ & $542(88.13 \%)$ & \multirow{4}{*}{$\begin{array}{c}1.03(0.78-1.36) \\
p=0.83\end{array}$} & \multirow{4}{*}{$\begin{array}{c}0.95(0.70-1.29)^{\mathrm{a}} \\
\mathrm{p}=0.73\end{array}$} \\
\hline & $\mathrm{A} 3 \mathrm{~B}+/-$ & $235(11.70 \%)$ & $68(11.06 \%)$ & & \\
\hline & $\mathrm{A} 3 \mathrm{~B}-1-$ & $10(0.50 \%)$ & $5(0.81 \%)$ & & \\
\hline & $\mathrm{A} 3 \mathrm{~B}+/-$ and $\mathrm{A} 3 \mathrm{~B}-/-$ & $245(12.20 \%)$ & $73(11.87 \%)$ & & \\
\hline \multirow{4}{*}{$\begin{array}{l}\text { GDANSK+SZCZECIN } \\
\text { BC cases }(n=2532) \text { vs. } \\
\text { unselected controls } \\
(n=2858)\end{array}$} & $\mathrm{A} 3 \mathrm{~B}+/+$ & $2214(87.44 \%)$ & $2492(87.19 \%)$ & \multirow{4}{*}{$\begin{array}{c}0.98(0.83-1.15) \\
p=0.79\end{array}$} & \multirow{4}{*}{$\begin{array}{c}0.97(0.83-1.14)^{b} \\
p=0.73\end{array}$} \\
\hline & $\mathrm{A} 3 \mathrm{~B}+/-$ & $306(12.09 \%)$ & $358(12.53 \%)$ & & \\
\hline & $\mathrm{A} 3 \mathrm{~B}-1-$ & $12(0.47 \%)$ & $8(0.28 \%)$ & & \\
\hline & $\mathrm{A} 3 \mathrm{~B}+/-$ and $\mathrm{A} 3 \mathrm{~B}-/-$ & $318(12.56 \%)$ & $366(12.81 \%)$ & & \\
\hline \multirow{4}{*}{$\begin{array}{l}\text { GDANSK+SZCZECIN } \\
\text { familial BC cases } \\
(n=640) \text { vs. unselected } \\
\text { controls }(n=2858)\end{array}$} & $\mathrm{A} 3 \mathrm{~B}+/+$ & $554(86.56 \%)$ & $2492(87.19 \%)$ & \multirow{4}{*}{$\begin{array}{c}1.06(0.82-1.36) \\
p=0.67\end{array}$} & \multirow{4}{*}{$\begin{array}{c}1.15(0.87-1.52)^{b} \\
p=0.32\end{array}$} \\
\hline & $\mathrm{A} 3 \mathrm{~B}+1-$ & $84(13.13 \%)$ & $358(12.53 \%)$ & & \\
\hline & $\mathrm{A} 3 \mathrm{~B}-1-$ & $2(0.31 \%)$ & $8(0.28 \%)$ & & \\
\hline & $\mathrm{A} 3 \mathrm{~B}+/-$ and $\mathrm{A} 3 \mathrm{~B}-/-$ & $86(13.44 \%)$ & $366(12.81 \%)$ & & \\
\hline
\end{tabular}

adjusted for age; badjusted for the origin of the study.

different cancer types and different sizes [published and available in PubMed up to February 2017 [17, 25, 31, $32,34,36-41]$. It has to be noted that the results obtained in the analyses are inconsistent and even conflicting. To obtain a more global view on the effect of the $A P O B E C 3 B$ deletion on cancer, we conducted a comprehensive metaanalysis that considered all case-control studies of the deletion (including our own) performed using cases with different cancer types (predominantly breast cancer). In total, 17637 cases and 19387 controls were enrolled in our meta-analysis (not including single studies of the deletion association with cervical, oral [38] and hepatocellular [32] cancer) (Figure 3A). As shown in Figure $3 \mathrm{~A}$, our meta-analysis revealed the consistent association of the $A P O B E C 3 B$ deletion with breast cancer in Asian populations $[\mathrm{OR}(95 \% \mathrm{CI})=1.367(1.282-1.458)$, $\mathrm{p}<0.001]$, but in European populations, the effect of the $A P O B E C 3 B$ deletion was much smaller and not significant $[\mathrm{OR}(95 \% \mathrm{CI})=1.102(0.995-1.221), \mathrm{p}=0.063]$. A single study of a north African population also did not show an association of the $A P O B E C 3 B$ deletion with breast cancer. Consequently, meta-analysis in the general population showed significant but modest association of the $A P O B E C 3 B$ deletion with breast cancer $[\mathrm{OR}(95 \% \mathrm{CI})=1.193(1.055-1.348), \mathrm{p}=0.005]$. Additionally, our meta-analysis revealed the lack of the association of the $A P O B E C 3 B$ deletion with ovarian cancer $[\mathrm{OR}(95 \% \mathrm{CI})=1.070(0.558-2.052), \mathrm{p}=0.839]$ and opposite association (protective effect) of the deletion with bladder cancer $[\mathrm{OR}(95 \% \mathrm{CI})=0.834(0.734-0.948), \mathrm{p}=0.005]$. It has to be noted, however, that these latter two meta-analyses have much lower statistical power (each composed of only two studies). Additionally, Middlebrooks and colleagues [41] showed that the effect of the $A P O B E C 3 B$ deletion on bladder cancer is mostly driven by SNP rs1014971 [being in linkage disequilibrium (LD) with the deletion], and mostly disappears after adjustment for this SNP genotype $[\mathrm{OR}(95 \% \mathrm{CI})=0.88(0.72-1.07), \mathrm{p}=0.21$ and $0.96(0.79-1.16), \mathrm{p}=0.67$ in European and Japanese populations, respectively]. In the forest plot summarizing 
Table 2: Analysis of the association of the $A P O B E C 3 B$ deletion with ovarian cancer risk using dominant model of inheritance (A3B+/- and A3B-/- vs. A3B $+/+$ )

\begin{tabular}{|c|c|c|c|c|c|}
\hline Group & Genotypes & $\begin{array}{c}\text { No of cases } \\
(\%)\end{array}$ & $\begin{array}{c}\text { No of controls } \\
(\%)\end{array}$ & OR(95\%CI) & $\begin{array}{c}\text { Adjusted } \\
\text { OR(95\%CI) }\end{array}$ \\
\hline \multirow{4}{*}{$\begin{array}{l}\text { GDANSK: OC } \\
\text { cases }(n=343) \text { vs. } \\
\text { unselected controls } \\
(n=853)\end{array}$} & $\mathrm{A} 3 \mathrm{~B}+/+$ & $313(91.25 \%)$ & $759(88.98 \%)$ & \multirow{4}{*}{$\begin{array}{c}0.77(0.50-1.19) \\
\mathrm{p}=0.24\end{array}$} & \multirow{4}{*}{-} \\
\hline & $\mathrm{A} 3 \mathrm{~B}+1-$ & $28(8.16 \%)$ & $91(10.67 \%)$ & & \\
\hline & A3B-1- & $2(0.58 \%)$ & $3(0.35 \%)$ & & \\
\hline & $\mathrm{A} 3 \mathrm{~B}+/-$ and $\mathrm{A} 3 \mathrm{~B}-/-$ & $30(8.75 \%)$ & $94(11.02 \%)$ & & \\
\hline \multirow{4}{*}{$\begin{array}{l}\text { VILNIUS: OC } \\
\text { cases }(n=97) \text { vs. } \\
\text { unselected controls } \\
(n=209)\end{array}$} & $\mathrm{A} 3 \mathrm{~B}+/+$ & $90(92.78 \%)$ & $187(89.47 \%)$ & \multirow{4}{*}{$\begin{array}{c}0.66(0.27-1.61) \\
\mathrm{p}=0.36\end{array}$} & \multirow{4}{*}{-} \\
\hline & $\mathrm{A} 3 \mathrm{~B}+1-$ & $6(6.19 \%)$ & $22(10.53 \%)$ & & \\
\hline & $\mathrm{A} 3 \mathrm{~B}-1-$ & $1(1.03 \%)$ & $0(0 \%)$ & & \\
\hline & $\mathrm{A} 3 \mathrm{~B}+/-$ and $\mathrm{A} 3 \mathrm{~B}-/-$ & $7(7.22 \%)$ & $22(10.53 \%)$ & & \\
\hline \multirow{4}{*}{$\begin{array}{l}\text { GDANSK + } \\
\text { VILNIUS: OC } \\
\text { cases }(n=440) \text { vs. } \\
\text { unselected controls } \\
(n=1062)\end{array}$} & $\mathrm{A} 3 \mathrm{~B}+/+$ & $403(91.59 \%)$ & $946(89.08 \%)$ & \multirow{4}{*}{$\begin{array}{c}0.75(0.51-1.10) \\
\mathrm{p}=0.14\end{array}$} & \multirow{4}{*}{$\begin{array}{c}0.75(0.51-1.11)^{b} \\
p=0.15\end{array}$} \\
\hline & $\mathrm{A} 3 \mathrm{~B}+1-$ & $34(7.73 \%)$ & $113(10.64 \%)$ & & \\
\hline & $\mathrm{A} 3 \mathrm{~B}-1-$ & $3(0.68 \%)$ & $3(0.28 \%)$ & & \\
\hline & $\mathrm{A} 3 \mathrm{~B}+/-$ and $\mathrm{A} 3 \mathrm{~B}-/-$ & $37(8.41 \%)$ & $116(10.92 \%)$ & & \\
\hline
\end{tabular}

${ }^{\mathrm{b}}$ Adjusted for the origin of the study.

the $A P O B E C 3 B$ deletion association studies (Figure 3A), we also included the results of Revathidevi and colleagues [38] and Zhang and colleagues [32], which were only studies of cervical/oral and HBV-related hepatocellular cancer, respectively, and were therefore not included in the meta-analysis. The frequency of the deletion allele varies significantly across different ethnic groups/ geographic regions. Drastic differences in the $A P O B E C 3 B$ deletion frequency among populations suggest that it is subjected to different selective pressures in human populations, it is functionally important, and it possesses the potential to modify phenotypes. It transpires that the worldwide distribution of the deletion frequency among control groups from studies enrolled in our meta-analysis resembles the distribution previously determined by Kidd and colleagues [18], with a mean frequency of $28.5 \%$ in Asia and 7.8\% in Europe (worldwide frequency: 19.33\%), which indicates that the studies enrolled in our metaanalysis are reliable and devoid of evident genotyping errors/biases (Figure 3B).

\section{DISCUSSION}

The two major reasons for the recent significant intensification of efforts on understanding the functional importance of the $A P O B E C 3 B$ gene are (i) the observation that activation of $A P O B E C 3 B$ in cancer leads to the generation of specific hypermutation signatures in breast and other cancer genomes $[55,57,58]$ and (ii) the association of the $A P O B E C 3 B$ gene deletion with breast cancer risk $[17,25]$.

The aim of our study was to extend the current knowledge of the structure of the $A P O B E C 3 B$ deletion, its influence on the expression of the affected genes, and its association with breast and ovarian cancer predisposition in the European population. We determined the exact structure/breakpoints of the $A P O B E C 3 B$ deletion (1 nt resolution) and showed that although the breakpoints are located in highly homologous regions that may induce NAHR ([74, 75] and references within) and trigger recurrent occurrence of similar but not identical deletions, there is no sign of deletion heterogeneity. Even a small heterogeneity in the breakpoint positions would prevent the A3Bdel_PCR test from detecting the deletion and would cause discordance between A3Bdel PCR and A3Bdel_MLPA results (not observed in our study in the panel of HapMap samples from European, African and Asiatic populations). This result strongly suggests that the deletion occurred in a single event (most likely in Africa) and then spread with the migration throughout the world, becoming common in European and Asiatic/Oceanic populations. Similar conclusions could not be derived from haplotype analysis due to low LD of flanking SNPs with the deletion [18]. We also delivered evidence of the presence of the hybrid $A P O B E C 3 A / A P O B E C 3 B$ transcript in individuals carrying allele with the $A P O B E C 3 B$ 
deletion and confirmed its suggested structure [18, 27] with $1 \mathrm{nt}$ resolution. These findings allowed us to distinguish canonical $A P O B E C 3 A$ and $A P O B E C 3 B$ genes/ transcripts from the hybrid $A P O B E C 3 A / A P O B E C 3 B$ and develop several molecular assays, i.e., A3Bdel_PCR, A3Bdel_MLPA, and A3A_exp, A3B_exp and A3A/A3B exp, which the scientific community can use in further analyses of the complex genomic region encompassing the $A P O B E C 3 B$ deletion. It has to be noted that assays $\mathrm{A} 3 \mathrm{~A}$ exp, $\mathrm{A} 3 \mathrm{~B}$ exp and $\mathrm{A} 3 \mathrm{~A} / \mathrm{A} 3 \mathrm{~B}$ exp allow for an efficient distinction of the highly homologous canonical ( $A P O B E C 3 A$ and $A P O B E C 3 B$ ) and hybrid $A P O B E C 3 A$ / $A P O B E C 3 B$ transcripts and constitute an important extension of the available qPCR assays (either UPLor TaqMan/SYBR Green-based) [55, 64, 72, 76-79] dedicated only for the analysis of canonical transcripts. E.g., in contrast to the previously developed assays, our A3A/A3B_exp assay allows to detect $A P O B E C 3 A$ / $A P O B E C 3 B$ transcript not only if present alone in samples with the homozygous A3B-/- deletion (e.g., [64]) but also if present on background of the other genotypes. The accuracy of transcript distinguishing of the A3A_exp, A3B_exp, and A3A/A3B_exp assays was validated using sequence analysis of PCR products (e.g., Supplementary Figure 2, lower panel). The lack of signal of the A3A_exp and $\mathrm{A} 3 \mathrm{~B}$ _exp assays in samples with homozygous deletion and lack of signal of the A3A/A3B_exp assay in samples without deletion additionally confirm the specificity of the developed assays and unequivocally show that the assays allow distinguishing the canonical and hybrid transcripts. Additionally, the developed expression assays are free of missmapping/cross-hybridization effects, affecting previously reported microarray- and RNAseqbased results and hampering distinguishing the highly homologous $A P O B E C 3 A$ and $A P O B E C 3 B$ transcripts (see also Figure 2A). This problem was reported and described with more details previously [64]. The proposed assays are cost effective [several cents (PCR genotyping) to $\sim 5 \$$ (MLPA) per sample)], provide reliable results and can be utilized in large-scale association and functional studies of the $A P O B E C 3 B$ deletion.

In our study, we showed for the first time the association of the $A P O B E C 3 B$ deletion with the expression of all affected genes, including the $A P O B E C 3 A$ / $A P O B E C 3 B$ hybrid. We performed expression analysis using the ddPCR and UPL-qPCR methods in the lymphoblastoid cell lines (in total: 12) with the naturally occurring genotypes in a natural genetic background. Additionally, we supported our results with data extracted from genome-wide datasets. Our analysis showed that the $A P O B E C 3 B$ deletion negatively correlates with the expression of $A P O B E C 3 A$ and $A P O B E C 3 B$ and positively correlates with the expression of $A P O B E C 3 A$ / $A P O B E C 3 B$. Additionally, it showed that the $A P O B E C 3 B$ expression level is much higher $(>100 \mathrm{x})$ than the expression of $A P O B E C 3 A$, which is still higher $(>10 \mathrm{x})$ than the expression of the APOBEC $3 A / A P O B E C 3 B$ hybrid. Much higher expression of the canonical $A P O B E C 3 A$ than of the $A P O B E C 3 A / A P O B E C 3 B$ hybrid gene indicates that the loss of $A P O B E C 3 A$ expression that goes with the deletion is not compensated by the increased level of the hybrid. As $A P O B E C 3 A$ and $A P O B E C 3 A$ / $A P O B E C 3 B$ transcripts differ only by their 3'UTRs, it strongly supports the role of the 3'UTR in differential regulation of these two sister genes, suggesting the loss of a positive regulatory element or acquisition of a negative regulatory element (decreasing transcription efficiency or stability of hybrid transcript) specific for the 3'UTR of $A P O B E C 3 B$. This result clearly contrasts with the results of Caval et al. [73] who with the use of artificially created model genes (constructed in plasmids and transfected into human cells) demonstrated increased expression of the transcript with the $A P O B E C 3 B$ 3'UTR. The discordance between our results and the results of Caval et al. [73] is most likely a consequence of the difference between natural and plasmid-based expression system and/ or different types of cell lines used in the experiments. On the other hand, our expression results are generally inline with the results of Starrett et al. [64] who, also using artificial model (CRISPR/Cas9 generated deletion), showed high expression of $A P O B E C 3 B$ and very low but similar expression of $A P O B E C 3 A$ and $A P O B E C 3 A$ / $A P O B E C 3 B$. The previous studies of the $A P O B E C 3 B$ deletion genotype-expression relationship (i) did not distinguish the canonical $A P O B E C 3 A$ and the hybrid $A P O B E C 3 A / A P O B E C 3 B$ transcripts, and/or (ii) were conducted using artificially created cell line models with transfected reporter constructs, and/or (iii) were performed with the use of single tissue or cell line samples, and/or (iv) were often inconclusive, at least partially due to high homology between $A P O B E C 3 A$ and $A P O B E C 3 B$, as well as other members of the $A P O B E C 3$ gene family [32, 33, $40,63,64,73,78,80,81]$.

Unequivocal confirmation of the presence of hybrid transcript (generated from A3B-allele) may strengthen the notion/hypothesis that the APOBEC3A enzyme generated from the $A P O B E C 3 A / A P O B E C 3 B$ hybrid transcript may play an important role in the induction of kataegis [73]. This notion is inline with observations showing that amount of somatic mutations occurring in APOBEC3specific sequence context is on average higher in cancer samples with the homozygous $A P O B E C 3 B$ deletion $[63,64]$. On the other hand, the very low expression level of $A P O B E C 3 A$ and even lower expression of the $A P O B E C 3 A / A P O B E C 3 B$ hybrid argues against this hypothesis and may suggest that some other member of the APOBEC3 family may play the role in generation of the APOBEC3-dependent somatic mutations. Recently, it was shown that such a gene may be one of the several variants (haplotypes) of $A P O B E C 3 H$ (i.e., $A P O B E C 3 H-I$ ), which occurrence across human population additionally correlates with the occurrence of the $A P O B E C 3 B$ deletion 

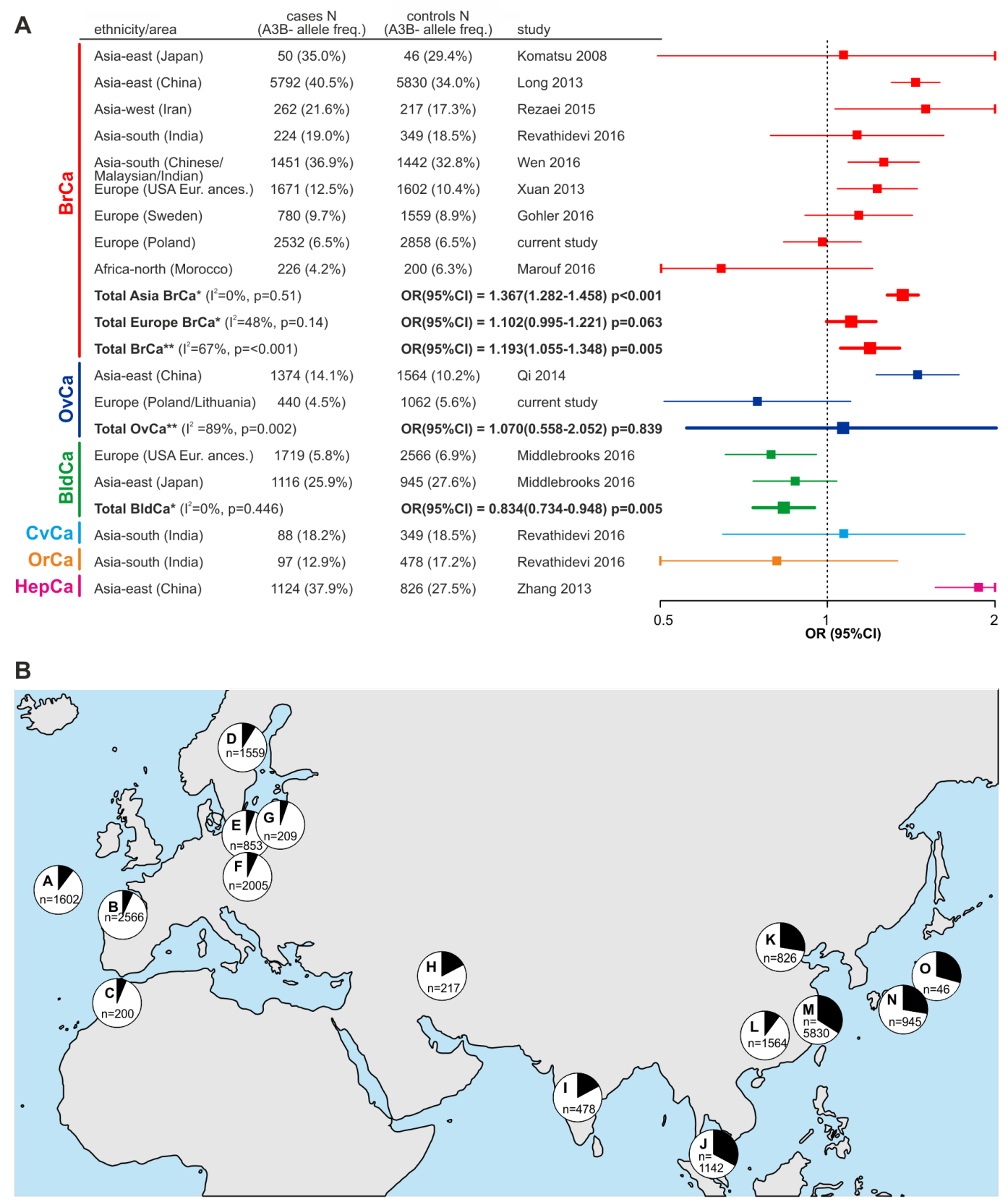

Figure 3: Meta-analysis of association studies of the $A P O B E C 3 B$ deletion with breast and other types of cancer. (A) Forest plot summarizing results of the meta-analysis. Characteristics of the studies used in the meta-analysis are shown on the left side of the plot. The plot illustrates the measure of the effect of the $A P O B E C 3 B$ deletion on predisposition to particular cancer types, i.e., OR (square) with the corresponding 95\% CI (horizontal lines), observed in different studies enrolled in the meta-analysis. The meta-analysis was performed under the dominant model of inheritance (A3B+/+ and $\mathrm{A} 3 \mathrm{~B}+/-$ vs. A3B-/-). Weighted odds ratios with the corresponding 95\%Cis (squares with horizontal lines in bold) were obtained using Mantel-Haenszel method under fixed* or random** effects models, depending on results of heterogeneity tests ( $\mathrm{p}>0.10$ for the $\mathrm{Q}$ test and $\mathrm{I}<50 \%$ were considered to indicate a lack of significant heterogeneity). The vertical dotted line indicates no effect $(\mathrm{OR}=1)$ of the $A P O B E C 3 B$ deletion on cancer predisposition. The OR values are plotted on a logarithmic scale to obtain symmetrical CIs and equivalent visualization of ORs of values greater and lower than 1 . Horizontal lines corresponding to CIs that are out of range of 0.5-2 have been cut (vertical line) for visualization purposes. $\mathrm{BrCa}$ - breast cancer; OvCa - ovarian cancer; $\mathrm{BldCa}$ - bladder cancer; $\mathrm{CvCa}$ - cervical cancer; $\mathrm{OrCa}$ - oral cancer; $\mathrm{HepCa}$ - hepatocellular cancer. (B) Worldwide distribution of the allelic frequencies (black segments in pie charts) of the $A P O B E C 3 B$ deletion in control groups used in studies that were enrolled in the meta-analysis. Each letter indicates particular geographic region/population from a particular study, i.e., A - USA European ancestry [31]; B - Spain/USA European ancestry [41]; C - Morocco [39]; D - Sweden [37]; E - Poland (GDANSK) (current study); F - Poland (SZCZECIN) (current study); G - Lithuania (VILNIUS) (current study); H - Iran [36]; I - India [38]; J - Malaysia [40]; K - China [32]; L - China [34]; M - China [17]; N - Japan [41]; O - Japan [25]. " $n$ " indicates the number of samples in the control groups in each study. 
[64]. It has to be noted, however, that the above part of the discussion is very speculative and based on often conflicting pieces of evidence reported in different studies. It indicates that much more has to be done to explain the role of the $A P O B E C 3$ genes and the $A P O B E C 3 B$ deletion in the induction of somatic mutations in cancer.

In the next step, we performed a large-scale association study of the $A P O B E C 3 B$ deletion with breast and/or ovarian risk, which encompassed either separate or appropriately combined analyses of three European cohorts, i.e., GDANSK, SZCZECIN and VILNIUS. Our association study comprised 2972 cases and 3682 controls; it was the largest $A P O B E C 3 B$ deletion association study performed in European populations and the first $A P O B E C 3 B$ deletion association study to use the familial form of breast cancer. Our analysis revealed the lack of association of the $A P O B E C 3 B$ deletion with breast cancer risk and additionally did not show association of the deletion with familial breast cancer risk. As familial breast cancer represents a more extreme phenotype, one could expect it to show a stronger effect of the association. Therefore, the lack of association of the $A P O B E C 3 B$ deletion with familial breast cancer additionally confirms no effect of the deletion in the European population. Similarly, we also show the lack of the association of the deletion with ovarian cancer. To obtain a more global view of the relationship between the $A P O B E C 3 B$ deletion and cancer predisposition, we performed a comprehensive multilayer meta-analysis of all available studies on the association of the $A P O B E C 3 B$ deletion with cancer predisposition conducted in different populations and geographic regions. Although the metaanalysis showed substantial heterogeneity in the results obtained by different groups and a moderate global effect of the $A P O B E C 3 B$ deletion, it revealed a consistent association of the $A P O B E C 3 B$ deletion with breast cancer in Asian populations but a lack of this association in European populations. It has to be noted, however, that the association in Asian populations is driven mostly by a large seminal study [17]. The general overlap of the geographical distribution of the $A P O B E C 3 B$ deletion frequency observed in the meta-analyzed association studies with that observed before [18] exclude substantial genotyping inaccuracy in the association studies as the main source of the discordances of the $A P O B E C 3 B$ deletion effect in Asiatic and European populations. Therefore, we believe that the main source of the discordances may be differences in genetic background, such as the presence of some other causative genetic variants that in Asiatic populations share the haplotype with the $A P O B E C 3 B$ deletion but are absent or not in LD with the deletion in European populations. Some support for this hypothesis may be the analysis of HapMap Phase I SNPs that revealed different pattern of LD in regions flanking the deletion in European and Asiatic populations [18]. This analysis showed SNPs in regions directly adjacent to the deletion being in moderate LD with the deletion in Asiatic but not in European populations. Additionally, analysis of the Northern European population showed a lack of SNPs in strong LD with the deletion [37]. Later, analysis of 1000 Genomes Project data identified only one surrogate SNP, i.e., rs12628403, that showed complete LD with the deletion in a European population, lower LD in a Chinese population, and very low LD in an African population [17, 41]. Additionally, the presence of interfering environmental factors specific to particular geographic regions/populations cannot be excluded. The observed drastic differences of the frequency of the $A P O B E C 3 B$ deletion in different populations strongly support the notion of an interaction between environmentally driven selective pressure and the deletion. The function of APOBEC3B that may play a role in selective pressure may be its potential involvement in response against viral infections, e.g., HBV or HTLV1 infection [32, 44-46], or its suggested role in innate immunity against malaria [29]. However, there are some controversies and a lack of consensus on the involvement of APOBEC3B in the restriction of particular types of viruses, e.g., HIV1 (e.g., [26, 28, 33, 42]; reviewed in [20]).

Our study is not free of limitations. Our association analysis involved relatively small numbers of samples from women with ovarian cancer, which limits its power to detect potential associations with ovarian cancer risk. The performed meta-analysis is very heterogeneous in terms of proband ethnicity, geographical regions, cancer types and cancer characteristics. Additionally, some ethnic groups or geographical regions are not represented at all; e.g., there is only one small study of an African population (including no study of African-Americans) and no study of South American populations. It limits the power of some more specific (e.g., ethnic-specific) conclusions. Some studies included in the meta-analysis are very small $(<<500$ samples) with limited statistical power. Moreover, our expression analyses were performed with the use of only one type of cell lines. We cannot exclude that the $A P O B E C 3 B$ deletion effect may be different in different cell lines or tissues.

In conclusion, in this study, we determined the exact breakpoints of the $A P O B E C 3 B$ deletion (1 nt resolution) and confirmed its homogeneity. Additionally, we provided direct evidence for the generation of the transcriptionally active hybrid gene $A P O B E C 3 A / A P O B E C 3 B$ from the allele with the $A P O B E C 3 B$ deletion and confirmed the suggested structure of $A P O B E C 3 A / A P O B E C 3 B$, which allowed us to distinguish $A P O B E C 3 A, A P O B E C 3 B$, and $A P O B E C 3 A / A P O B E C 3 B$ expression levels. For the first time, we showed the association of the $A P O B E C 3 B$ deletion with the expression of all affected genes, including the $A P O B E C 3 A / A P O B E C 3 B$ hybrid. We observed that the expression of $A P O B E C 3 A / A P O B E C 3 B$ is $\sim 10 \mathrm{x}$ lower than the expression of $A P O B E C 3 A$, which 
implies the role of the 3'UTR in the differential regulation of these two genes coding for the same protein. We showed a lack of association of the $A P O B E C 3 B$ deletion with breast and/or ovarian risk (for the first time including familial breast cancer), which was independently validated in three European cohorts (in total: 2972 cases and 3682 controls). We also performed a comprehensive summary/ visualization of all available reports on the association of the $A P O B E C 3 B$ deletion with cancer predisposition, which was obtained in our meta-analysis of association studies performed in various populations and geographic regions. It also has to be noted that within our study, we developed a variety of molecular assays that can be used for further analysis of the complex genomic region encompassing the $A P O B E C 3 B$ deletion.

\section{MATERIALS AND METHODS}

\section{DNA samples}

To compare the $A P O B E C 3 B$ deletion genotype with the expression of the affected genes, we used 270 reference DNA samples from the basic (phaseI/II) HapMap panel, including (i) 90 African samples from the Yoruba in Ibadan, Nigeria (YRI); (ii) 90 samples from individuals from Utah, USA, from the Centre d'Etude du Polymorphisme Humain collection (CEU); (iii) 45 samples from Han Chinese in Beijing, China (CHB); (iv) 45 samples from Japanese in Tokyo, Japan (JPT). All DNA samples were purchased from Coriell Institute for Medical Research (NJ, USA).

The $A P O B E C 3 B$ deletion association study was performed using genomic DNA samples from casecontrol groups collected at the Medical University of Gdansk (GDANSK group), at the International Hereditary Cancer Center in Szczecin (SZCZECIN group) and at Vilnius University Hospital Santariskiu Klinikos, Lithuania (VILNIUS group). All subjects from GDANSK, SZCZECIN, and VILNIUS provided informed written consent, and the study was approved by the appropriate local ethic committees. All subjects were Caucasians of European ancestry. Subjects from GDANSK and SZCZECIN were ethnically Poles. Subjects from VILNIUS were of mixed ethnicity, composed mostly of Lithuanians $(\sim 60 \%)$ but also Poles and Russians, with similar fractions of the ethnicities in case and control groups. In all groups, the control samples were derived from the same geographical region as the case samples.

The GDANSK group comprised 523 BC-cases [women with breast cancer from families with breast and/or ovarian cancer aggregation, as defined previously [82], negative for the 5 most common BRCA1 mutations in the Polish population, c.68_69delAG, c.181T> G, c.3700_3704del5, c.4035delA, c.5266dupC [83, 84], 343 OC-cases (women with ovarian cancer unselected in terms of the familial history of the disease), and 853 controls (unselected population control samples).

The SZCZECIN group comprised 2009 BC-cases (women with breast cancer, unselected for familial history of the disease) and two distinct sets of control samples: 2005 SZCZECIN controls (cancer-free unselected women) and 615 SZCZECIN NH-controls (cancer-free women with a negative family history of cancer). Histological subtypes were determined for 1397 SZCZECIN BC-cases, of which 1117 (79.96\%) were invasive ductal carcinoma, $128(9.16 \%)$ were invasive lobular carcinoma, 47 (3.36\%) were ductal carcinoma in situ, 24 (1.72\%) were carcinoma medullare, $22(1.57 \%)$ were carcinoma mucinosum, and 1-17 (0.07-1.22\%) were of other subtypes of breast cancer. Breast cancer grade was determined for 1047 SZCZECIN BC-cases, of which 737 (70.39\%) and 310 $(29.61 \%)$ were classified as G1/G2 and G3, respectively. Status of estrogen receptor (ER) was determined for 1372 SZCZECIN BC-cases, of which 416 (30.32\%) and 956 (69.68\%) were ER negative and ER positive, respectively. Status of progesterone receptor (PgR) was determined for 1365 SZCZECIN BC-cases, of which 450 (32.97\%) and 915 (67.03\%) were PgR negative and PgR positive (PgR+), respectively. Status of human epidermal growth factor receptor 2 (HER2) was determined for 1291 SZCZECIN BC-cases, of which 1037 (80.33\%) and 254 (19.67\%) were HER2 negative and HER2 positive, respectively. Triplenegative (TN) status of breast cancer was determined for 218 SZCZECIN BC-cases (17.30\% of cases in which all three receptors were tested). Information about familial history of cancer was recorded for 1590 cases, of which $117(7.36 \%)$ were classified as familial breast cancer cases (according to criteria previously defined in [85]). The mean age of breast cancer diagnosis in SZCZECIN BC-cases was 54 years (range 21-92), with 187 (9.31\%), 712 (35.44\%) and 1110 (55.25\%) women diagnosed before age 40, between the ages 40 and 50, and after age 50, respectively. A total of $52(2.6 \%)$ SZCZECIN BC-cases were positive for one of three major $B R C A 1$ founder mutations in the Polish population, i.e., c. $181 \mathrm{~T}>\mathrm{G}$, c.4035delA, and c.5266dupC. SZCZECIN controls included women with a mean age of 52 years (range 17-94), and SZCZECIN $\mathrm{NH}$-controls included women with a mean age of 67 years (range 36-95).

The VILNIUS group comprised 97 OC-cases (women with unselected ovarian cancer) and 209 controls (samples from unselected control population). Mean age of ovarian cancer diagnosis in VILNIUS OC-cases was 53 years (range 18-78). VILNIUS controls comprised women with mean age of 44 years (range 18-85).

\section{Analysis of the structure of the $A P O B E C 3 B$ deletion}

Sequencing analyses were performed using ABI Prism 3130XL apparatus (Applied Biosystems, Carlsbad, 
CA, USA). The obtained sequences were analyzed with the use of Finch TV (v.1.4.0) (Geospiza Inc.).

MLPA analysis was performed using the in-house designed A3Bdel_MLPA assay. The probe-set layout was designed according to a previously proposed $[65,66]$ and well-validated strategy (e.g., [67, 86-88]). This strategy exclusively utilized short oligonucleotide probes that can easily be generated via standard chemical synthesis. Each probe consists of two half-probes of equal size, and the total probe length ranges from 93 to $128 \mathrm{nt}$. The target sequences for the probes were selected to avoid single nucleotide polymorphisms (SNPs), insertions/deletions, and sequences of extremely low or high guanosinecytosine (GC) content. The sequences and detailed characteristics of all probes are shown in Supplementary Table 1. The MLPA probes were synthesized by IDT (Skokie, IL, USA). The MLPA reactions were run according to the manufacturer's general recommendations and previously published $[65,89]$, with reagents purchased from MRC-Holland, Amsterdam, The Netherlands. The products of the MLPA reactions were diluted $20 \times$ in HiDi formamide containing GS Liz600, which was used as a DNA sizing standard, and separated by size with capillary electrophoresis (POP7 polymer; ABI Prism 3130XL apparatus; Applied Biosystems, Carlsbad, CA, USA). The obtained electropherograms were analyzed using GeneMarker software (version 2.2.0; SoftGenetics, State College, PA, USA). The normalized signal of each probe (peak height divided by the average peak height of the control probes) was divided by the corresponding signal of a reference probe and multiplied by 2 . The obtained values that correspond to the copy number of particular regions were visualized in bar graphs.

\section{Analysis of the $A P O B E C 3 B$ deletion genotype- expression relationship}

Publically available genome-wide mRNA profiling data of different panels of HapMap samples that were used in our study are deposited at Gene Expression Omnibus (GEO) (http://www.ncbi.nlm.nih.gov/geo) database (series accession number: GSE6536), and Array Express database (https:/www.ebi.ac.uk/arrayexpress/; accession number: E-MTAB-197 and E-MTAB-198) as well as at http:// jungle.unige.ch/rnaseq_CEU60/ (file with normalized data "RNASEQ60_array_rep_expr.txt.gz"). The $A P O B E C 3 B$ deletion genotypes of the analyzed HapMap samples were determined before [18] and independently confirmed in our study.

Human lymphoblastoid cell lines (LCLs) GM18532, GM18537, GM18540, GM18542, GM18561, GM18570, GM18572, GM18573, GM18577, GM18579, GM18603, and GM18612 from the HapMap panel were purchased from the Coriell Institute for Medical Research (USA; http://www.coriell.org). All cell lines were cultured in Dulbecco's Modified Eagle Medium (DMEM; Lonza, Basel, Switzerland) supplemented with 10\% fetal bovine serum (FBS; Sigma-Aldrich, St. Louis, MO, USA), 1\% Glutamax (Cellgro, Mediatech Inc., Manassas, VA, USA), $1 \mathrm{x}$ antibiotic/antimycotic solution (Sigma-Aldrich), and $1 \mathrm{x}$ MEM non-essential amino acid solution (Sigma-Aldrich). Mycoplasma infection in cell cultures was controlled with the use of the MycoFluor ${ }^{\mathrm{TM}}$ Mycoplasma Detection Kit (Invitrogen, Carlsbad, CA, USA) according to the manufacturer's protocol.

Total RNA was extracted from cells with TRIzol (Invitrogen) according to the manufacturer's instructions. Equal amounts of RNA $(2 \mu \mathrm{g})$ were reverse-transcribed with random primers (Invitrogen) using SuperScript III Reverse Transcriptase (Invitrogen) according to the manufacturer's protocol.

ddPCR was performed according to the manufacturer's general recommendations (Bio-Rad, CA, USA). ddPCR reactions (containing $1 \times$ EvaGreen Supermix, $200 \mathrm{nM}$ primers, one-twentieth of cDNA to a final volume of $20 \mu \mathrm{L}$ ) were mixed with seventy microliters of droplet generation oil and used to form droplets in a QX200 droplet generator. The partitioned emulsion was then slowly transferred to a 96-well PCR plate (Eppendorf, Hamburg, Germany). After being heatsealed with foil, the plates containing the droplets were PCR cycled to final point under conditions at $95^{\circ} \mathrm{C}$ for 5 min, then $95^{\circ} \mathrm{C}$ for $30 \mathrm{~s}$, and $56^{\circ} \mathrm{C}$ for $30 \mathrm{~s}$, and $72^{\circ} \mathrm{C}$ for $45 \mathrm{~s}$ for 40 cycles, $72^{\circ} \mathrm{C}$ for $2 \mathrm{~min}, 4^{\circ} \mathrm{C}$ for $5 \mathrm{~min}, 90^{\circ} \mathrm{C}$ for $5 \mathrm{~min}$, then held at $12^{\circ} \mathrm{C}$. Following PCR, samples were read on a Bio-Rad QX200 reader and data were analyzed using Quantasoft software v.1.7.4.0917 (Bio-Rad, CA, USA). Primers used in the ddPCR analyses were designed at the exon-exon junctions or in different, adjacent exons spanning a long intron to avoid amplification of the potential gDNA traces. For each analyzed cDNA sample, the following sets of PCR primers were used: (i) A3B_exp, i.e., test amplicon for $A P O B E C 3 B$ : Fwd primer 5'GACCTACGATGAGTTTGAGT3', Rev primer 5'TTAGAGACTGAGGCCCAT3' (amplicon length: 163 bp); (ii) A3A_exp, i.e., test amplicon for $A P O B E C 3 A$ : Fwd primer 5'CATTCTCCAGAATCAGGG3', Rev primer 5'CTTGATCGGGAGCATAC 3' (amplicon length: $170 \mathrm{bp}$ ); (iii) A3A/A3B_exp, i.e., test amplicon for $A P O B E C 3 A / A P O B E C 3 B$ hybrid: Fwd primer 5'TGACCTACGATGAATTTAAGC3', Rev primer 5'ATCTACTTGATCAGGAGCAC3' (amplicon length: 293 bp), (iv) reference amplicon for GAPDH: Fwd primer 5'CACCACCAACTGCTTAGC3', Rev primer 5'CATGGACTGTGGTCATGAG3' (amplicon length: 87 $\mathrm{bp)}$.

UPL-qPCR analyses were performed with the use of LightCycler 480 system with probes from the Universal Probe Library (UPL) (Roche Applied Science, Penzberg, Germany), according to the manufacturer's protocol. For test amplicons, the same primer sets were used as in the ddPCR analyses. The following set of PCR primers was used as a reference amplicon for $A C T B$ : Fwd 
primer 5'CCAACCGCGAGAAGATGA3', Rev primer 5'CCAGAGGCGTACAGGGATAG3' (amplicon length: $97 \mathrm{bp}$ ). The applied primers-UPL probes combinations were as follows: (i) $A P O B E C 3 B$ test amplicon, probe \#11; (ii) $A P O B E C 3 A$ test amplicon, probe \#13; (iii) $A P O B E C 3 A / A P O B E C 3 B$ hybrid test amplicon, probe \#13; (iv) $A C T B$ reference amplicon, probe \#64. qPCR assays were run in triplicates for 45 cycles and normalized tested gene expression level was calculated by the formula: $2^{-\Delta \mathrm{Ct}}$, where $\Delta \mathrm{Ct}=\mathrm{Ct}_{\text {test amplicon }}-\mathrm{Ct}_{\text {reference amplicon }}$, using the LightCycler 480 instrument software.

\section{A3Bdel_PCR assay for genotyping of the APOBEC $3 B$ deletion}

Genotyping of the $A P O B E C 3 B$ deletion was performed with the use of A3Bdel_PCR assay that consists of three PCR primers, i.e., one forward primer F: 5'CCTGTCCCTTTTCAGAATTTAAGC3', and two reverse primers: R1: 5'CTTGATCGGGAGCATAC3' (complementary to reference allele; $\mathrm{F}+\mathrm{R} 1$ amplicon length: $572 \mathrm{bp}$ ), and R2: 5'TGGAGCCAATTAATCACTTCAT3' (complementary to deletion allele, F+R2 amplicon length: $707 \mathrm{bp}$ ). All three primers were used simultaneously in each single reaction. PCR was performed in a $6.25-\mu 1$ reactions composed of $0.3 \mu \mathrm{l}$ of $10 \mu \mathrm{M}$ dilution of each primer (synthesized by Sigma-Aldrich), $0.125 \mu \mathrm{l}$ of dNTPs mix (Promega, Madison, WI, USA), $0.05 \mu \mathrm{l}$ of GoTaq DNA Polymerase (concentration $5 \mathrm{u} / \mu \mathrm{l}$ ) (Promega), 1.25 $\mu \mathrm{l}$ of $5 \mathrm{X}$ colorless GoTaq reaction buffer (containing 7.5 $\mathrm{mM} \mathrm{MgCl}$ ) (Promega), $2.925 \mu$ l of deionized water, and $1 \mu 1$ of DNA ( $\sim 30 \mathrm{ng})$. The following cycling conditions were used: 2 min at $95^{\circ} \mathrm{C}$, followed by 35 cycles at $95^{\circ} \mathrm{C}$ for $20 \mathrm{sec}, 56^{\circ} \mathrm{C}$ for $20 \mathrm{sec}$, and $72^{\circ} \mathrm{C}$ for $5 \mathrm{~min}$, followed by $5 \mathrm{~min}$ at $72^{\circ} \mathrm{C}$. The obtained PCR products were visualized on a standard $1.5 \%$ agarose gel.

\section{Statistical methods}

The $A P O B E C 3 B$ deletion genotype-expression relationship was analyzed with the use of one-way analysis of variance (ANOVA) with post-test for linear trend, and t-test using Prism v. 4.0 (GraphPad, San Diego, CA).

HWE was assessed in the control groups using the chi-square test. Associations between the APOBEC $3 B$ deletion and breast or ovarian cancer risk were assessed using ORs and 95\%CIs derived from logistic regression models. ORs $(95 \% \mathrm{CIs})$ were estimated in the analyses assuming different models of inheritance, i.e., dominant $(\mathrm{A} 3 \mathrm{~B}+/-$ and $\mathrm{A} 3 \mathrm{~B}-/-$ vs. $\mathrm{A} 3 \mathrm{~B}+/+$ ), recessive $(\mathrm{A} 3 \mathrm{~B}-/-$ vs. $\mathrm{A} 3 \mathrm{~B}+/-$ and $\mathrm{A} 3 \mathrm{~B}+/+)$, and additive $(\mathrm{A} 3 \mathrm{~B}-/-$ vs. $\mathrm{A} 3 \mathrm{~B}+/-$ vs. $\mathrm{A} 3 \mathrm{~B}+/+)$ models. Appropriate adjustments for the origin of the study and age (when data regarding age were available for particular case-control groups) were applied. Meta-analysis was performed with the use of MantelHaenszel method assuming dominant model of inheritance.
MedCalc Statistical Software version 14.8.1 (MedCalc Software bvba, Ostend, Belgium; http://www.medcalc .org) was used for all logistic regression analyses and metaanalysis. All statistical tests were two-sided, and a p-value less than 0.05 was considered statistically significant.

\section{Author contributions}

KK - designed and optimized MLPA test and performed MLPA analyses, developed genotyping test and conducted genotyping analyses, designed expression assay and performed genotype-expression analyses, performed all statistical analyses and meta-analysis, participated in manuscript preparation, including tables, figures and supporting materials; WK - performed genotyping of samples from the SZCZECIN cohort; BR - performed genotyping of samples from the SZCZECIN cohort; AJ participated in the SZCZECIN samples characterization/ selection and participated in manuscript preparation; MR characterized samples from the GDANSK group, participated in manuscript preparation, coordinated the Poznan-Gdansk cooperation; NK - participated in genotyping of samples from the VILNIUS cohort; DV - provided, characterized and genotyped samples from the VILNIUS cohort; KC - performed cell cultures and RNA extraction from the lymphoblastoid HapMap cell lines; MW - performed cell cultures and RNA extraction the lymphoblastoid HapMap cell lines; CC - coordinated the Poznan-Szczecin cooperation and genotyping analysis of samples from the SZCZECIN cohort and participated in manuscript preparation; JL - founder of Szczecin International Hereditary Cancer Centre (IHCC) samples collection, selected samples for analysis, discussed the concept of manuscript; PK - conceived and coordinated the study and collaboration with the Gdansk and Szczecin research groups, supervised all analyses, prepared (with $\mathrm{KK}$ ) the manuscript including tables, figures and supporting materials.

\section{ACKNOWLEDGMENTS}

We thank the Laboratory of Subcellular Structures Analysis of the Institute of Bioorganic Chemistry, Polish Academy of Sciences in Poznan, for the use LightCycler 480 system (Roche). All capillary electrophoresis separations were conducted in Laboratory of Molecular Biology Techniques, Faculty of Biology, Adam Mickiewicz University, Poznan.

\section{CONFLICTS OF INTEREST}

All authors declare no conflicts of interest.

\section{FUNDING}

This work was supported by research grants 2015/19/N/NZ5/02247 (recipient: KK) and 2015/17/B/ 
NZ2/01182 (recipient: PK) from the National Science Centre, Poland (http://www.ncn.gov.pl/) and KNOW program of the Polish Ministry of Science and Higher Education.

\section{REFERENCES}

1. Lichtenstein P, Holm NV, Verkasalo PK, Iliadou A, Kaprio J, Koskenvuo M, Pukkala E, Skytthe A, Hemminki K. Environmental and heritable factors in the causation of cancer--analyses of cohorts of twins from Sweden, Denmark, and Finland. N Engl J Med. 2000; 343:78-85.

2. Beggs AD, Hodgson SV. Genomics and breast cancer: the different levels of inherited susceptibility. Eur J Hum Genet. 2009; 17:855-856.

3. Ripperger T, Gadzicki D, Meindl A, Schlegelberger B. Breast cancer susceptibility: current knowledge and implications for genetic counselling. Eur J Hum Genet. 2009; 17:722-731.

4. Melchor L, Benitez J. The complex genetic landscape of familial breast cancer. Hum Genet. 2013; 132:845-863.

5. Walsh T, King MC. Ten genes for inherited breast cancer. Cancer Cell. 2007; 11:103-105.

6. Foulkes WD. Inherited susceptibility to common cancers. N Engl J Med. 2008; 359:2143-2153.

7. Eccles SA, Aboagye EO, Ali S, Anderson AS, Armes J, Berditchevski F, Blaydes JP, Brennan K, Brown NJ, Bryant HE, Bundred NJ, Burchell JM, Campbell AM, et al. Critical research gaps and translational priorities for the successful prevention and treatment of breast cancer. Breast Cancer Res. 2013; 15:R92.

8. Michailidou K, Hall P, Gonzalez-Neira A, Ghoussaini M, Dennis J, Milne RL, Schmidt MK, Chang-Claude J, Bojesen SE, Bolla MK, Wang Q, Dicks E, Lee A, et al. Large-scale genotyping identifies 41 new loci associated with breast cancer risk. Nat Genet. 2013; 45:353-361, 361e351-352.

9. Michailidou K, Beesley J, Lindstrom S, Canisius S, Dennis J, Lush MJ, Maranian MJ, Bolla MK, Wang Q, Shah M, Perkins BJ, Czene K, Eriksson M, et al. Genome-wide association analysis of more than 120,000 individuals identifies 15 new susceptibility loci for breast cancer. Nat Genet. 2015; 47:373-380.

10. Manolio TA, Collins FS, Cox NJ, Goldstein DB, Hindorff LA, Hunter DJ, McCarthy MI, Ramos EM, Cardon LR, Chakravarti A, Cho JH, Guttmacher AE, Kong A, et al. Finding the missing heritability of complex diseases. Nature. 2009; 461:747-753.

11. Gonzalez E, Kulkarni H, Bolivar H, Mangano A, Sanchez R, Catano G, Nibbs RJ, Freedman BI, Quinones MP, Bamshad MJ, Murthy KK, Rovin BH, Bradley W, et al. The influence of CCL3L1 gene-containing segmental duplications on HIV-1/AIDS susceptibility. Science. 2005; 307:1434-1440.

12. Yang TL, Chen XD, Guo Y, Lei SF, Wang JT, Zhou Q, Pan F, Chen Y, Zhang ZX, Dong SS, Xu XH, Yan H, Liu X, et al. Genome-wide copy-number-variation study identified a susceptibility gene, UGT2B17, for osteoporosis. Am J Hum Genet. 2008; 83:663-674.

13. Bentley RW, Pearson J, Gearry RB, Barclay ML, McKinney C, Merriman TR, Roberts RL. Association of higher DEFB4 genomic copy number with Crohn's disease. Am J Gastroenterol. 2010; 105:354-359.

14. Celestino-Soper PB, Shaw CA, Sanders SJ, Li J, Murtha MT, Ercan-Sencicek AG, Davis L, Thomson S, Gambin T, Chinault AC, Ou Z, German JR, Milosavljevic A, et al. Use of array CGH to detect exonic copy number variants throughout the genome in autism families detects a novel deletion in TMLHE. Hum Mol Genet. 2011; 20:4360-4370.

15. Krepischi AC, Achatz MI, Santos EM, Costa SS, Lisboa BC, Brentani H, Santos TM, Goncalves A, Nobrega AF, Pearson PL, Vianna-Morgante AM, Carraro DM, Brentani $R R$, et al. Germline DNA copy number variation in familial and early-onset breast cancer. Breast Cancer Res. 2012; 14:R24.

16. Suehiro Y, Okada T, Shikamoto N, Zhan Y, Sakai K, Okayama N, Nishioka M, Furuya T, Oga A, Kawauchi S, Maeda N, Tamesa M, Nagashima Y, et al. Germline copy number variations associated with breast cancer susceptibility in a Japanese population. Tumour Biol. 2013; 34:947-952.

17. Long J, Delahanty RJ, Li G, Gao YT, Lu W, Cai Q, Xiang YB, Li C, Ji BT, Zheng Y, Ali S, Shu XO, Zheng W. A common deletion in the APOBEC3 genes and breast cancer risk. J Natl Cancer Inst. 2013; 105:573-579.

18. Kidd JM, Newman TL, Tuzun E, Kaul R, Eichler EE. Population stratification of a common APOBEC gene deletion polymorphism. PLoS Genet. 2007; 3:e63.

19. Conticello SG. The AID/APOBEC family of nucleic acid mutators. Genome Biol. 2008; 9:229.

20. Moris A, Murray S, Cardinaud S. AID and APOBECs span the gap between innate and adaptive immunity. Front Microbiol. 2014; 5:534.

21. Swanton C, McGranahan N, Starrett GJ, Harris RS. APOBEC enzymes: mutagenic fuel for cancer evolution and heterogeneity. Cancer Discov. 2015; 5:704-712.

22. Rebhandl S, Huemer M, Greil R, Geisberger R. AID/ APOBEC deaminases and cancer. Oncoscience. 2015; 2:320-333.

23. Henderson S, Fenton T. APOBEC3 genes: retroviral restriction factors to cancer drivers. Trends Mol Med. 2015; 21:274-284.

24. Burns MB, Leonard B, Harris RS. APOBEC3B: pathological consequences of an innate immune DNA mutator. Biomed J. 2015; 38:102-110.

25. Komatsu A, Nagasaki K, Fujimori M, Amano J, Miki Y. Identification of novel deletion polymorphisms in breast cancer. Int J Oncol. 2008; 33:261-270.

26. An P, Johnson R, Phair J, Kirk GD, Yu XF, Donfield S, Buchbinder S, Goedert JJ, Winkler CA. APOBEC3B 
deletion and risk of HIV-1 acquisition. J Infect Dis. 2009; 200:1054-1058.

27. Abe H, Ochi H, Maekawa T, Hatakeyama T, Tsuge M, Kitamura S, Kimura T, Miki D, Mitsui F, Hiraga N, Imamura M, Fujimoto Y, Takahashi S, et al. Effects of structural variations of APOBEC 3A and APOBEC3B genes in chronic hepatitis B virus infection. Hepatol Res. 2009; 39:1159-1168.

28. Itaya S, Nakajima T, Kaur G, Terunuma H, Ohtani H, Mehra N, Kimura A. No evidence of an association between the APOBEC3B deletion polymorphism and susceptibility to HIV infection and AIDS in Japanese and Indian populations. J Infect Dis. 2010; 202:815-816; author reply 816-817.

29. Jha P, Sinha S, Kanchan K, Qidwai T, Narang A, Singh PK, Pati SS, Mohanty S, Mishra SK, Sharma SK, Awasthi S, Venkatesh V, Jain S, et al. Deletion of the APOBEC3B gene strongly impacts susceptibility to falciparum malaria. Infect Genet Evol. 2012; 12:142-148.

30. Ezzikouri S, Kitab B, Rebbani K, Marchio A, WainHobson S, Dejean A, Vartanian JP, Pineau P, Benjelloun S. Polymorphic APOBEC3 modulates chronic hepatitis B in Moroccan population. J Viral Hepat. 2013; 20:678-686.

31. Xuan D, Li G, Cai Q, Deming-Halverson S, Shrubsole MJ, Shu XO, Kelley MC, Zheng W, Long J. APOBEC3 deletion polymorphism is associated with breast cancer risk among women of European ancestry. Carcinogenesis. 2013; 34:2240-2243.

32. Zhang T, Cai J, Chang J, Yu D, Wu C, Yan T, Zhai K, Bi X, Zhao H, Xu J, Tan W, Qu C, Lin D. Evidence of associations of APOBEC3B gene deletion with susceptibility to persistent HBV infection and hepatocellular carcinoma. Hum Mol Genet. 2013; 22:1262-1269.

33. Imahashi M, Izumi T, Watanabe D, Imamura J, Matsuoka K, Ode H, Masaoka T, Sato K, Kaneko N, Ichikawa S, Koyanagi Y, Takaori-Kondo A, Utsumi M, et al. Lack of association between intact/deletion polymorphisms of the APOBEC3B gene and HIV-1 risk. PLoS One. 2014; 9:e92861.

34. Qi G, Xiong H, Zhou C. APOBEC3 deletion polymorphism is associated with epithelial ovarian cancer risk among Chinese women. Tumour Biol. 2014; 35:5723-5726.

35. Prasetyo AA, Sariyatun R, Reviono, Sari Y, Hudiyono, Haryati S, Adnan ZA, Hartono, Kageyama S. The APOBEC3B deletion polymorphism is associated with prevalence of hepatitis B virus, hepatitis $\mathrm{C}$ virus, Torque Teno virus, and Toxoplasma gondii co-infection among HIV-infected individuals. J Clin Virol. 2015; 70:67-71.

36. Rezaei M, Hashemi M, Hashemi SM, Mashhadi MA, Taheri $\mathrm{M}$. APOBEC3 deletion is associated with breast cancer risk in a sample of southeast Iranian population. Int J Mol Cell Med. 2015; 4:103-108.

37. Gohler S, Da Silva Filho MI, Johansson R, EnquistOlsson K, Henriksson R, Hemminki K, Lenner P, Forsti A. Impact of functional germline variants and a deletion polymorphism in APOBEC3A and APOBEC3B on breast cancer risk and survival in a Swedish study population. J Cancer Res Clin Oncol. 2016; 142:273-276.

38. Revathidevi S, Manikandan M, Rao AK, Vinothkumar V, Arunkumar G, Rajkumar KS, Ramani R, Rajaraman R, Ajay C, Munirajan AK. Analysis of APOBEC3A/3B germline deletion polymorphism in breast, cervical and oral cancers from South India and its impact on miRNA regulation. Tumour Biol. 2016; 37:11983-11990.

39. Marouf C, Gohler S, Filho MI, Hajji O, Hemminki K, Nadifi S, Forsti A. Analysis of functional germline variants in APOBEC3 and driver genes on breast cancer risk in Moroccan study population. BMC Cancer. 2016; 16:165.

40. Wen WX, Soo JS, Kwan PY, Hong E, Khang TF, Mariapun S, Lee CS, Hasan SN, Rajadurai P, Yip CH, Mohd Taib NA, Teo SH. Germline APOBEC3B deletion is associated with breast cancer risk in an Asian multi-ethnic cohort and with immune cell presentation. Breast Cancer Res. 2016; 18:56.

41. Middlebrooks CD, Banday AR, Matsuda K, Udquim KI, Onabajo OO, Paquin A, Figueroa JD, Zhu B, Koutros S, Kubo M, Shuin T, Freedman ND, Kogevinas M, et al. Association of germline variants in the APOBEC3 region with cancer risk and enrichment with APOBEC-signature mutations in tumors. Nat Genet. 2016; 48:1330-1338.

42. Singh H, Marathe SD, Nain S, Nema V, Ghate MV, Gangakhedkar RR. APOBEC3B deletion impacts on susceptibility to acquire HIV-1 and its advancement among individuals in western India. APMIS. 2016; 124:881-887.

43. Han Y, Qi Q, He Q, Sun M, Wang S, Zhou G, Sun Y. APOBEC3 deletion increases the risk of breast cancer: a meta-analysis. Oncotarget. 2016; 7:74979-74986. https:// doi.org/ 10.18632/oncotarget.11792.

44. Ooms M, Krikoni A, Kress AK, Simon V, Munk C. APOBEC3A, APOBEC3B, and APOBEC3H haplotype 2 restrict human T-lymphotropic virus type 1. J Virol. 2012; 86:6097-6108.

45. Suspene R, Guetard D, Henry M, Sommer P, Wain-Hobson $\mathrm{S}$, Vartanian JP. Extensive editing of both hepatitis B virus DNA strands by APOBEC3 cytidine deaminases in vitro and in vivo. Proc Natl Acad Sci U S A. 2005; 102:8321-8326.

46. Zhang W, Zhang X, Tian C, Wang T, Sarkis PT, Fang Y, Zheng S, Yu XF, Xu R. Cytidine deaminase APOBEC3B interacts with heterogeneous nuclear ribonucleoprotein $\mathrm{K}$ and suppresses hepatitis B virus expression. Cell Microbiol. 2008; 10:112-121.

47. Vartanian JP, Guetard D, Henry M, Wain-Hobson S. Evidence for editing of human papillomavirus DNA by APOBEC3 in benign and precancerous lesions. Science. 2008; 320:230-233.

48. Warren CJ, Xu T, Guo K, Griffin LM, Westrich JA, Lee D, Lambert PF, Santiago ML, Pyeon D. APOBEC3A functions as a restriction factor of human papillomavirus. J Virol. 2015; 89:688-702. 
49. Stenglein MD, Harris RS. APOBEC3B and APOBEC3F inhibit L1 retrotransposition by a DNA deamination-independent mechanism. J Biol Chem. 2006; 281:16837-16841.

50. Muckenfuss H, Hamdorf M, Held U, Perkovic M, Lower J, Cichutek K, Flory E, Schumann GG, Munk C. APOBEC3 proteins inhibit human LINE-1 retrotransposition. J Biol Chem. 2006; 281:22161-22172.

51. Kinomoto M, Kanno T, Shimura M, Ishizaka Y, Kojima A, Kurata T, Sata T, Tokunaga K. All APOBEC3 family proteins differentially inhibit LINE-1 retrotransposition. Nucleic Acids Res. 2007; 35:2955-2964.

52. Carpenter MA, Li M, Rathore A, Lackey L, Law EK, Land AM, Leonard B, Shandilya SM, Bohn MF, Schiffer CA, Brown WL, Harris RS. Methylcytosine and normal cytosine deamination by the foreign DNA restriction enzyme APOBEC3A. J Biol Chem. 2012; 287:34801-34808.

53. Wijesinghe $\mathrm{P}$, Bhagwat AS. Efficient deamination of 5-methylcytosines in DNA by human APOBEC3A, but not by AID or APOBEC3G. Nucleic Acids Res. 2012; 40:9206-9217.

54. Fu Y, Ito F, Zhang G, Fernandez B, Yang H, Chen XS. DNA cytosine and methylcytosine deamination by APOBEC3B: enhancing methylcytosine deamination by engineering APOBEC3B. Biochem J. 2015; 471:25-35.

55. Burns MB, Lackey L, Carpenter MA, Rathore A, Land AM, Leonard B, Refsland EW, Kotandeniya D, Tretyakova N, Nikas JB, Yee D, Temiz NA, Donohue DE, et al. APOBEC3B is an enzymatic source of mutation in breast cancer. Nature. 2013; 494:366-370.

56. Chan K, Roberts SA, Klimczak LJ, Sterling JF, Saini N, Malc EP, Kim J, Kwiatkowski DJ, Fargo DC, Mieczkowski PA, Getz G, Gordenin DA. An APOBEC3A hypermutation signature is distinguishable from the signature of background mutagenesis by APOBEC3B in human cancers. Nat Genet. 2015; 47:1067-1072.

57. Nik-Zainal S, Alexandrov LB, Wedge DC, Van Loo P, Greenman CD, Raine K, Jones D, Hinton J, Marshall J, Stebbings LA, Menzies A, Martin S, Leung K, et al. Mutational processes molding the genomes of 21 breast cancers. Cell. 2012; 149:979-993.

58. Roberts SA, Sterling J, Thompson C, Harris S, Mav D, Shah R, Klimczak LJ, Kryukov GV, Malc E, Mieczkowski PA, Resnick MA, Gordenin DA. Clustered mutations in yeast and in human cancers can arise from damaged long single-strand DNA regions. Mol Cell. 2012; 46:424-435.

59. Burns MB, Temiz NA, Harris RS. Evidence for APOBEC3B mutagenesis in multiple human cancers. Nat Genet. 2013; 45:977-983.

60. Leonard B, Hart SN, Burns MB, Carpenter MA, Temiz NA, Rathore A, Vogel RI, Nikas JB, Law EK, Brown WL, Li Y, Zhang Y, Maurer MJ, et al. APOBEC3B upregulation and genomic mutation patterns in serous ovarian carcinoma. Cancer Res. 2013; 73:7222-7231.

61. Roberts SA, Lawrence MS, Klimczak LJ, Grimm SA, Fargo D, Stojanov P, Kiezun A, Kryukov GV, Carter SL, Saksena
G, Harris S, Shah RR, Resnick MA, et al. An APOBEC cytidine deaminase mutagenesis pattern is widespread in human cancers. Nat Genet. 2013; 45:970-976.

62. Taylor BJ, Nik-Zainal S, Wu YL, Stebbings LA, Raine K, Campbell PJ, Rada C, Stratton MR, Neuberger MS. DNA deaminases induce break-associated mutation showers with implication of APOBEC3B and 3A in breast cancer kataegis. Elife. 2013; 2:e00534.

63. Nik-Zainal S, Wedge DC, Alexandrov LB, Petljak M, Butler AP, Bolli N, Davies HR, Knappskog S, Martin S, Papaemmanuil E, Ramakrishna M, Shlien A, Simonic I, et al. Association of a germline copy number polymorphism of APOBEC3A and APOBEC3B with burden of putative APOBEC-dependent mutations in breast cancer. Nat Genet. 2014; 46:487-491.

64. Starrett GJ, Luengas EM, McCann JL, Ebrahimi D, Temiz NA, Love RP, Feng Y, Adolph MB, Chelico L, Law EK, Carpenter MA, Harris RS. The DNA cytosine deaminase APOBEC3H haplotype I likely contributes to breast and lung cancer mutagenesis. Nat Commun. 2016; 7:12918.

65. Kozlowski P, Roberts P, Dabora S, Franz D, Bissler J, Northrup H, Au KS, Lazarus R, Domanska-Pakiela D, Kotulska K, Jozwiak S, Kwiatkowski DJ. Identification of 54 large deletions/duplications in TSC1 and TSC2 using MLPA, and genotype-phenotype correlations. Hum Genet. 2007; 121:389-400.

66. Marcinkowska M, Wong KK, Kwiatkowski DJ, Kozlowski P. Design and generation of MLPA probe sets for combined copy number and small-mutation analysis of human genes: EGFR as an example. ScientificWorldJournal. 2010; 10:2003-2018.

67. Marcinkowska-Swojak M, Uszczynska B, Figlerowicz M, Kozlowski P. An MLPA-based strategy for discrete CNV genotyping: CNV-miRNAs as an example. Hum Mutat. 2013; 34:763-773.

68. Marcinkowska-Swojak M, Klonowska K, Figlerowicz M, Kozlowski P. An MLPA-based approach for high-resolution genotyping of disease-related multi-allelic CNVs. Gene. 2014; 546:257-262.

69. Stranger BE, Nica AC, Forrest MS, Dimas A, Bird CP, Beazley C, Ingle CE, Dunning M, Flicek P, Koller D, Montgomery S, Tavare S, Deloukas P, et al. Population genomics of human gene expression. Nat Genet. 2007; 39:1217-1224.

70. Montgomery SB, Sammeth M, Gutierrez-Arcelus M, Lach RP, Ingle C, Nisbett J, Guigo R, Dermitzakis ET. Transcriptome genetics using second generation sequencing in a Caucasian population. Nature. 2010; 464:773-777.

71. Koning FA, Newman EN, Kim EY, Kunstman KJ, Wolinsky SM, Malim MH. Defining APOBEC3 expression patterns in human tissues and hematopoietic cell subsets. J Virol. 2009; 83:9474-9485.

72. Refsland EW, Stenglein MD, Shindo K, Albin JS, Brown WL, Harris RS. Quantitative profiling of the full APOBEC3 mRNA repertoire in lymphocytes and tissues: 
implications for HIV-1 restriction. Nucleic Acids Res. 2010; 38:4274-4284.

73. Caval V, Suspene R, Shapira M, Vartanian JP, Wain-Hobson S. A prevalent cancer susceptibility APOBEC3A hybrid allele bearing APOBEC3B 3'UTR enhances chromosomal DNA damage. Nat Commun. 2014; 5:5129.

74. Stankiewicz P, Lupski JR. The genomic basis of disease, mechanisms and assays for genomic disorders. Genome Dyn. 2006; 1:1-16.

75. Weckselblatt B, Rudd MK. Human structural variation: mechanisms of chromosome rearrangements. Trends Genet. 2015; 31:587-599.

76. Sieuwerts AM, Willis S, Burns MB, Look MP, Meijer-Van Gelder ME, Schlicker A, Heideman MR, Jacobs H, Wessels L, Leyland-Jones B, Gray KP, Foekens JA, Harris RS, et al. Elevated APOBEC3B correlates with poor outcomes for estrogen-receptor-positive breast cancers. Horm Cancer. 2014; 5:405-413.

77. Law EK, Sieuwerts AM, LaPara K, Leonard B, Starrett GJ, Molan AM, Temiz NA, Vogel RI, Meijer-van Gelder ME, Sweep FC, Span PN, Foekens JA, Martens JW, et al. The DNA cytosine deaminase APOBEC3B promotes tamoxifen resistance in ER-positive breast cancer. Sci Adv. 2016; 2:e1601737.

78. Liu J, Sieuwerts AM, Look MP, van der Vlugt-Daane M, Meijer-van Gelder ME, Foekens JA, Hollestelle A, Martens JW. The $29.5 \mathrm{~kb}$ APOBEC3B deletion polymorphism is not associated with clinical outcome of breast cancer. PLoS One. 2016; 11:e0161731.

79. Sieuwerts AM, Schrijver WA, Dalm SU, de Weerd V, Moelans CB, Ter Hoeve N, van Diest PJ, Martens JW, van Deurzen CH. Progressive APOBEC3B mRNA expression in distant breast cancer metastases. PLoS One. 2017; 12:e0171343.

80. Cescon DW, Haibe-Kains B, Mak TW. APOBEC3B expression in breast cancer reflects cellular proliferation, while a deletion polymorphism is associated with immune activation. Proc Natl Acad Sci U S A. 2015; 112:2841-2846.

81. Tsuboi M, Yamane A, Horiguchi J, Yokobori T, KawabataIwakawa R, Yoshiyama S, Rokudai S, Odawara H, Tokiniwa H, Oyama T, Takeyoshi I, Nishiyama M. APOBEC3B high expression status is associated with aggressive phenotype in Japanese breast cancers. Breast Cancer. 2016; 23:780-788.
82. Ratajska M, Brozek I, Senkus-Konefka E, Jassem J, Stepnowska M, Palomba G, Pisano M, Casula M, Palmieri G, Borg A, Limon J. BRCA1 and BRCA2 point mutations and large rearrangements in breast and ovarian cancer families in Northern Poland. Oncol Rep. 2008; 19:263-268.

83. Gorski B, Jakubowska A, Huzarski T, Byrski T, Gronwald J, Grzybowska E, Mackiewicz A, Stawicka M, Bebenek M, Sorokin D, Fiszer-Maliszewska L, Haus O, Janiszewska H, et al. A high proportion of founder BRCA1 mutations in Polish breast cancer families. Int J Cancer. 2004; 110:683-686.

84. Szwiec M, Jakubowska A, Gorski B, Huzarski T, TomiczekSzwiec J, Gronwald J, Debniak T, Byrski T, Kluzniak W, Wokolorczyk D, Birkenfeld B, Akbari MR, Narod SA, et al. Recurrent mutations of BRCA1 and BRCA2 in Poland: an update. Clin Genet. 2015; 87:288-292.

85. Cybulski C, Carrot-Zhang J, Kluzniak W, Rivera B, Kashyap A, Wokolorczyk D, Giroux S, Nadaf J, Hamel N, Zhang S, Huzarski T, Gronwald J, Byrski T, et al. Germline RECQL mutations are associated with breast cancer susceptibility. Nat Genet. 2015; 47:643-646.

86. Klonowska K, Ratajska M, Czubak K, Kuzniacka A, Brozek I, Koczkowska M, Sniadecki M, Debniak J, Wydra D, Balut M, Stukan M, Zmienko A, Nowakowska B, et al. Analysis of large mutations in BARD1 in patients with breast and/ or ovarian cancer: the Polish population as an example. Sci Rep. 2015; 5:10424.

87. Czubak K, Lewandowska MA, Klonowska K, Roszkowski K, Kowalewski J, Figlerowicz M, Kozlowski P. High copy number variation of cancer-related microRNA genes and frequent amplification of DICER1 and DROSHA in lung cancer. Oncotarget. 2015; 6:4716. https://doi.org/10.18632/ oncotarget.4351.

88. Marcinkowska-Swojak M, Szczerbal I, Pausch H, Nowacka-Woszuk J, Flisikowski K, Dzimira S, Nizanski W, Payan-Carreira R, Fries R, Kozlowski P, Switonski $\mathrm{M}$. Copy number variation in the region harboring SOX9 gene in dogs with testicular/ovotesticular disorder of sex development (78,XX; SRY-negative). Sci Rep. 2015; 5:14696.

89. Schouten JP, McElgunn CJ, Waaijer R, Zwijnenburg D, Diepvens F, Pals G. Relative quantification of 40 nucleic acid sequences by multiplex ligation-dependent probe amplification. Nucleic Acids Res. 2002; 30:e57. 